\title{
China’s Energy Diplomacy: SOE Relations in the Context of Global Distribution and Investment Pattern
}

\author{
Hui-Chi Yeh ${ }^{1}$, Chi-Wei Yu ${ }^{2}$ \\ ${ }^{1}$ Politics and International Relations, University of Southampton, Southampton, UK \\ ${ }^{2}$ Department of Politics, National Taiwan University, Taipei, Taiwan \\ Email: H.Yeh@soton.ac.uk
}

Received September 23 ${ }^{\text {rd }}$, 2012; revised October 24 $4^{\text {th }}$, 2012; accepted November $7^{\text {th }}, 2012$

\begin{abstract}
This article addresses the mercantilist connotations of China's energy diplomacy through empirical and quantitative approaches by arguing that: firstly, the economic logic motivating Chinese enterprises is not the key variable in the formulation of foreign investment decisions; secondly, the energy security policies of the Chinese government are key variables which decide the distribution of SOEs' foreign investment; thirdly, China's energy diplomacy is mercantilist in nature due to the weakness of its SOEs in the structure of the international market; finally, under the premise of satisfying its government's energy security policy, SOEs have autonomy in their approaches to investment. Therefore, it may be reasoned that under specific conditions, mercantilism and liberalism can both explain China's energy diplomacy. This article provides compelling evidence supporting this reasoning, through analyzing cases studies in the Middle East, Central Asia and Africa.
\end{abstract}

Keywords: Mercantilism; China’s Energy Diplomacy; State Owned Enterprises (SOEs)

\section{Introduction}

China's establishment of energy strategies and diplomacy principles based on concepts of diversification and outreach, initiated the entry of its major state-owned companies into global markets and propagated substantial increases in global energy prices. Some viewed this in neo-colonialist terms, as it deepened the dependency of energy rich developing nations on China (Blair, 2007) and contributed little to poverty alleviation (Polgreen \& French, 2007). Others viewed such investments as mercantilist and aimed at strengthening national power. Nevertheless, both views fail to represent fully the overseas investments of Chinese energy corporations. There has been limited academic research on the geographical composition of Chinese energy diplomacy, most of which has been conducted by entrepreneurs and executives in Chinese energy corporations. $\mathrm{Xu}$ Xiaojie, the former director of the Office of Overseas Investment for the state-owned China National Petroleum Corporation (CNPC), discussed the role of China in future global energy strategies, and emphasized the relationship between the energy rich nations of Central Asia and the Middle East and China's energy security (Xu, 1998). Director Xin Zhang of the International Division of the CNPC and Deputy Wang Jiashu of the Mining Resources Committee of the China Mining Association (CMA) highlighted the significant role that the Middle East plays in China's energy diplomacy and security strategy (Wang, 2004; Li, 2003; Zekun, 2004).

The development of Chinese energy corporations has lagged behind Western counterparts, due in part to international mechanisms and systems for controlling energy prices by Middle Eastern nations. This makes regional investment decisions costly, and also contradicts the principle of diversification, which aims to reduce the risk of interference in domestic market prices. However, from recent global investment patterns of
Chinese energy corporations, the number of cases where extraction and ownership permits were purchased from oil producing countries greatly exceeded the number of direct oil purchase cases. This casts doubt on literature which emphasizes the Middle East's role in building energy security.

This article aims to test the dominant theory that China's energy diplomacy exhibits mercantilism, in order to adequately explain China's relations with energy rich developing nations. This article examines the contracts made by the CNPC, the China National Offshore Oil Corporation (CNOOC), and the China Petroleum \& Chemical Corporation (CPCC) with energy rich nations from 1993 to 2008, and analyzes the relationships between both private and public sectors.

In examining these relations, it is important to recognize regional dynamics, as resource endowments vary regionally. Consequently, selected regions should be endowed with substantial gas and petroleum resources. Therefore, Europe, AsiaPacific and South Asia are excluded. Secondly, mercantilism places strong emphasis on national/governmental interference in market principles or economic order. So when a host country's national power exceeds that of China, two sets of variables (interference from both the host country and Chinese government) may occur in testing processes. Consequently, the case studies selected focus upon Central Asia, the Middle East, and Africa.

\section{Mercantilism and the Growth of Neo-Mercantilism}

Despite the importance of mercantilism in international political economics, no universal definition exists (Mcdermott, 1999). Robert Gilpin cited economic nationalism when conceptualizing mercantilism and neo-mercantilism (Lairson \& Skidmore, 2002; Gilpin, 1987). Goldstein argued that economic 
activities represent national development and interests (Goldstein, 2003). Mercantilism originated from European nations' overseas expansion between 1500 and 1776, which was viewed as a nation's pursuit of power and wealth. In countries with declining economic performance, rent-seeking actors would adopt free trade and modern political economic measures to enhance national power economically. In these early stages of mercantilism, gold and silver represented national power and wealth, and led to over-emphasized protectionism (Schmiegelow \& Schmiegelow, 1975), through attempts to simultaneously increase import costs and exports (Buzan \& Little, 2009). This resulted in zero-sum schemes in the international economy.

However, from 1750 onwards, many countries were affected by the excessive importation of British products, which prompted less developed countries to embrace trade and domestic industry protectionism. Scholars, like Frederick List, who advocated protectionism and state interference, were termed neo-mercantilists. Unlike mercantilists, neo-mercantilists believed that nations should seek rare resources and potential markets abroad, in addition to determining national power through alternative measures including population, transportation systems, and wider definitions for economic power, rather than in terms of gold and silver (Bohning, 1979).

According to the definitions of mercantilism and neo-mercantilism, their characteristics could be categorized accordingly: firstly, the core concept conceived that economic activities depended on national development or interests (Goldstein, 2003); secondly, economic activities aimed to increase social welfare and national interests, and all national industries should be protected (Gilpin, 1987); thirdly, economic strategies advocated by mercantilism focused on protecting or developing domestic industries. These strategies include the provision of foreign aid or subsidies to boost domestic economic development, strengthen tariff or non-tariff barriers to protect domestic industries, or strengthen international competitiveness of domestic industries through economic or political subsidies; fourth, the concept of power and wealth was interchangeable (Dougherty \& Pfaltzgraff, 2002); finally, industrialization promoted economic development. Sound economic power was fundamental to protecting national sovereignty while industrialization further strengthened national military power (Gilpin, 1987).

Following WWII, when global economic markets embraced liberalization, the General Agreement on Tariffs and Trade (GATT) and World Trade Organization (WTO) began consolidating and implementing free trade, and progressively eliminating mercantilism. Moreover, the measurement of national power in gold and silver terms became outdated; like currency, these commodities became merely trading tools. In facing similar critiques, mercantilism faced strong opposition and led protectionism advocates to pursue alternative ideas, primarily in specialized or technology-intensive industries like energy, communication technology, and aviation (Held, Mcgrew, Goldblatt, \& Perraton, 1999).

Economic development began in East Asia after WWII, through the adoption of the development strategy of "Rational Planning”, directing markets when appropriate, protecting new and high technology industries, and integrating resources into technological growth (Wang, 2003). The theories associated with this development strategy were neo-protectionism and strategic trade theory. Neo-protectionism emphasized increasing import-export profits, while strategic trade theory criticized free trade theory and overlooked associated developmental weaknesses (Brander, 1995a). It focused on studying imperfect competition whilst emphasizing market structure in oligopolies (Markusen, Melvin, Kaempfer, \& Maskus, 1995).

Krugman argued that liberal opposition to US President Reagan contributed to the rise of strategic trade theory (Krugman, 1994). Different from conventional free trade policies, strategic trade theory stressed that active state interference in trade policies nurtured national power and economic development (Krugman, 1986); such factors are interdependent characteristics of oligopolies (Brander, 1995b). Consequently, profits from one firm might directly affect the decisions of another. In imperfect competitive markets, firms are mutually interdependent while governments could increase domestic industrial competitiveness through appropriate trade policies.

Strategic trade theory stresses the government's role in domestic industrial development. While conventional free trade theory promotes constant comparative advantage, strategic trade theory advocates dynamic comparative advantage, and suggests that government and industry are capable of fine-tuning comparative advantage. Two examples include investment in the Japanese semiconductor industry and support for the European aviation industry (Reimer \& Steigert, 2006). Moreover, comparative advantage might be altered by governmental and industrial accomplishments. This implies that under perfect free trade regulations, increased competitiveness could be achievable through governmental market interference. Thus, competition serves as the basis for international economic relationships. However, in imperfect competitive markets, the efforts of one government and industry to increase competitiveness might be offset by another, ultimately, propagating an "an eye for an eye" scenario in international economic relationships (Thurow, 1992).

\section{Hypothesis}

The hypothesis of this article conceives that Chinese energy diplomacy exhibits neo-mercantilism. This article developed four sub-hypotheses based on neo-mercantilist theory and recent developments in Chinese energy corporations and energy diplomacy.

The first sub-hypothesis conceptualizes that economic activities represent national interests. Thus, the key factor influencing economic activity is national interest rather than individual profits. For net oil importing countries, basic interests regard strengthening energy security. If the energy diplomacy of the target country resembles neo-mercantilism, the costs of investment and profits are not principal issues for energy corporations when making overseas investments. Therefore, the first subhypothesis is: the costs of investment and profits are not key issues for Chinese energy corporations when making overseas investments. The relationships are rather weak and insignificant, and since another major claim of neo-mercantilism, advocating development through "Rational Planning", then state interference and resource integration for boosting industrial development are appropriate. It is widely accepted that profit and investment decisions of individual firms may be mutually incompatible with the interests and decision-making logic of the nation. Therefore, under these conditions, it is expected that individual firms play comparatively less significant roles in making overseas investment decisions. Hence, the second sub-hypothesis is: when making overseas investment decisions, 
the main concern for Chinese energy corporations is to rationalize government policies on national energy security. Furthermore, though the political-economic system in China contributed to the assumption that Chinese energy diplomacy resembles neo-mercantilism, this partially overlooks the potential weaknesses of these corporations. The development of Chinese energy corporations only began when China implemented its open-access policies. When China established its energy policies based upon diversification and outreach, global energy markets were dominated by Western energy corporations. Under such conditions, overseas investments by Chinese energy corporations tended to display neo-mercantilism. Thus, the third sub-hypothesis is: The structure of the international energy market heavily contributed to the overseas investment scheme of Chinese energy corporations, which explains why Chinese energy corporations' investments overseas appear neomercantilist.

Conversely, though neo-mercantilism places great emphasis on government interference and industrial protection, the role of industry is significant. The case studies show (Downs, 2008) that such transformations may alter government interference in overseas investments. In old government-centred relationships, industry complied with government orders when making investments. However, the transforming relationship between the government and industry implies that Chinese corporations are embracing mergers and acquisitions, to lower investment costs, while simultaneously consolidating the role corporations play in global energy markets. Hence, the fourth sub-hypothesis is: The relationship between the government and state-owned enterprises (SOEs) is more optimized for energy corporations and determines investment decisions, since energy corporations are capable of allocating resources efficiently and merging with other trans-national corporations to circumvent direct-entry approaches.

\section{Categorization Criteria and Approach}

The empirical results of this study show that energy investments can be categorized into three categories according to the investment pattern. The first category addresses the investment based on the rights associated with oil fields. The host country government or state-owned energy corporations must participate in formulating investment contracts. These can further be divided into three sub-categories. Firstly, the right of exploration; a basic principle associated with oil fields. Corporations have the right to conduct underground investigations for oil reserves, regardless of whether they own any right over the field itself. Secondly, concerns the right to extraction. Though corporations have oil extraction rights in the host country, it must be conducted legitimately, which often involves sharing reserves locally. Thirdly, is the right to purchase oil fields and their associated rights; this permits oil extraction upon payment of related taxes. However, corporations do not have to share reserves locally.

The second category emphasizes the commercial supply of oil or gas, and has no relation to the rights of the oil field. Though the resource seller may be the host country or a thirdcountry energy corporation, the buyer does not have to comply with the host's regulations, tariffs, or tax system. Though contracts of this category are not restricted by host government interference, it is expected that prices will fluctuate through market mechanisms.
The third category addresses the issue of basic infrastructural development. Buyers of this category do not obtain tangible resource supplies. However, through the construction of basic infrastructure, e.g. refineries, pipes, and storage facilities, buyers may expand their flexibility in the energy market, through obtaining greater bargaining chips when negotiating with host governments or state-owned corporations. This contract type is built upon the basic energy related infrastructure in the host country, thus the host government or state-owned corporation is significant in formalizing contracts.

For energy importing nations, the ultimate goal of energy diplomacy is to build domestic energy security. Therefore, the most important mid-term goal is to secure imports of resources to meet domestic demand in the energy market. Another goal is to enhance the independence of energy corporations in overseas markets, to alleviate the fragility and sensitivity of the domestic energy market. Furthermore, higher levels of independence limit variations in domestic energy prices, arising from price fluctuations in international energy markets or regional conflicts.

The objective of this article is to test whether China's energy diplomacy displays neo-mercantilist tendencies through the distribution of overseas investment by Chinese energy corporations. It uses three criteria, based on variables (types of energy investment), categorization and evaluation, to distinguish the types of investment. The first evaluates whether the corporation acquires oil or gas products; the second measures the corporation's level of independence in the host country's energy market; and the third, assesses the contribution made to energy diplomacy. The order of the goals of energy diplomacy implies that the main concern for importing countries, apart from building energy security, lies in the acquisition of oil or gas products. Consequently, levels of independence and contributions to energy diplomacy, receive less attention. Therefore, this study focuses on the corporation's acquisition of resources and assigns weights accordingly. Thus, a weight of two or zero is assigned to corporations, based upon their respective resource obtaining capabilities.

The second criterion is to evaluate the integrity of the corporation's independence. For energy importing countries, one objective of energy diplomacy is to enhance the independence of domestic energy corporations in overseas markets. This independence is affected by interference from the host country or state-owned corporations and changes triggered by price variations in the energy market. Upon securing the right of extraction, corporations are obliged to share their harvest, thus, the corporation is influenced by the host country. Conversely, resource supply contracts depend strongly on price mechanisms in the energy markets.

Strictly speaking, these criteria impact differently on levels of independence. The right of extraction is considered a long-term deficiency, while disturbance arising from market price mechanisms is short-term and can often be offset. Hence, this study assigns the weight of one to completely independent corporations, .5 for disturbances caused by market mechanisms and zero if disturbances from the host country prevail.

The third criterion for weight assignment is the evaluation of the corporation's investment in basic infrastructure and contributions to energy diplomacy. In the energy industry, the construction and maintenance of basic infrastructure and exploration of oil fields requires substantial capital investment (Latourette, Bernstein, Hanson, Pernin, Knopman, \& Overton, 
2003). These are often bargaining chips which third-country energy corporations use when negotiating with host country governments or energy corporations. These chips aid the acquisition of the rights of extraction and are often key components in energy diplomacy. Corporations are assigned weights of 0.5 or zero, depending on their bargaining abilities. These criteria are summarized in Table 1, along with an overall weight for each investment category. The significance of this overall weight is also outlined.

In classifying and managing independent variables, it is necessary to review the hypothesis of this study. The objective is to test whether China's energy diplomacy is strongly linked with neo-mercantilism. The two core concepts are, firstly, that economic activities represent national interests and facilitate national support to industries. The first sub-hypothesis concerns whether Chinese energy corporations' investments in overseas markets are profitable. This question is rather complex and its evaluation is specific in the energy industry. Starting from 2007, the Fraser Institute of Canada annually interviewed over 350 executives of trans-national energy corporations. From these interviews, the Institute presented the investment cost assessments made by trans-national energy corporations to 133 global regions.

The report focused on sets of 16 questions, which included the fiscal conditions of the host country's upstream energy industry, tax system, local natural gas price, the trade-off for compromising with governments, regular uncertainties, environmental regulations, local infrastructure, trade rules, labour employment regulations, local public infrastructure, quality and coverage of geological database, labour capability, land issues, political stability, and the safety of investors and their property (Angevine \& Cameron, 2007).
The Likert Scale was used to distinguish the evaluations of each interviewee, and group the questions into distinct categories: encourages investment, facilitates investment decisions, slightly impedes investment decisions, strongly impedes investment decisions, and discourages investment (Angevine \& Cameron, 2007). Furthermore, the report proportioned the interviewee evaluations, thus each category was assigned twenty per cent respectively. For conducting regression analysis, the results for each question set were simplified into a single score. In order to present the score of a condition in a certain region, a weight from one to five was assigned to the five categories. Since different interviewees were surveyed, this study integrated the total number of annual interviewees to simplify the results. The results are reduced to a single score (Figure 1):

Finally, though independent variables were derived from studies between 2007 and 2010, the precision of this study is unaffected. Overseas investment from Chinese energy corporations first began in 1993; however, it wasn't until 2003 that large scale expansion of overseas markets commenced. Furthermore, a country's investment environment is not subject to extensive transient transformation unless political conflict occurs. With these preconditions, the report published in 2007 is capable of testing the evaluations made by executives of the energy industry from 2003 to 2006.

\section{China's Global Energy Investment Distribution and Geological Deposition}

\section{The Middle East}

Middle Eastern countries exercise stringent control on their domestic oil or gas resources (Cordesman \& Al-Rodhan, 2006), and thus are capable of interfering with markets. The energy

Table 1.

Weight of each dependent variable (categories of energy investment).

\begin{tabular}{|c|c|c|c|c|c|}
\hline $\begin{array}{c}\text { Weight } \\
\text { Investment category }\end{array}$ & $\begin{array}{l}\text { Directly } \\
\text { obtain oil } \\
\text { supply }\end{array}$ & $\begin{array}{l}\text { Independency } \\
\text { of energy } \\
\text { industry }\end{array}$ & $\begin{array}{l}\text { Beneficial for } \\
\text { other } \\
\text { negotiations }\end{array}$ & Weight & Investment category \\
\hline Right of exploration & 0 & 1 & .5 & 1.5 & $\begin{array}{l}\text { - Right of investigation, } \\
\text { - Incapable obtaining resources directly } \\
\text { - High levels of independence and bargaining power }\end{array}$ \\
\hline Right of exploitation & 2 & 0 & 0 & 2 & $\begin{array}{l}\text { - Acquires resources directly } \\
\text { - Shared extraction } \\
\text { - Lowered independence levels } \\
\text { - No bargaining power }\end{array}$ \\
\hline $\begin{array}{l}\text { Property right of oil } \\
\text { field }\end{array}$ & 2 & 1 & 0 & 3 & $\begin{array}{l}\text { - Ensured resource supply } \\
\text { - Vulnerable to market mechanisms }\end{array}$ \\
\hline Oil/gas supply & 2 & .5 & 0 & 2.5 & $\begin{array}{l}\text { - Ensured supply of resources } \\
\text { - High levels of independence }\end{array}$ \\
\hline Basic infrastructure & 0 & 1 & .5 & 1.5 & $\begin{array}{l}\text { - Incapable of securing resources directly } \\
\text { - Increased bargaining power through basic infrastructural } \\
\text { investment }\end{array}$ \\
\hline
\end{tabular}

Note: The interaction of the three criteria in each investment category results in an overall weight for each category. Corporations with the right of investigation, but incapable of obtaining resources directly, but which have a high level of independence and bargaining ability, have a weight of 1.5. Corporations with the right of extraction are able to acquire resources directly, though where the extraction is shared; the independence level is lowered and eliminates the bargaining power. These corporations are assigned a weight of two. Moreover, corporations with resource supply contracts ensure a supply of oil or gas; however, they are more vulnerable to energy price markets and are thus assigned a weight of 2.5. The fourth investment category, the acquisition of the right of the oil field, ensures a supply of resources while at the same time maintains high levels of independence. Such corporations are assigned with the highest weight of three. Lastly, though importing countries are incapable of obtaining resource supplies directly through basic infrastructural investment, they hold effective bargaining power through such investments, and thus, a weight of 1.5 is assigned. 


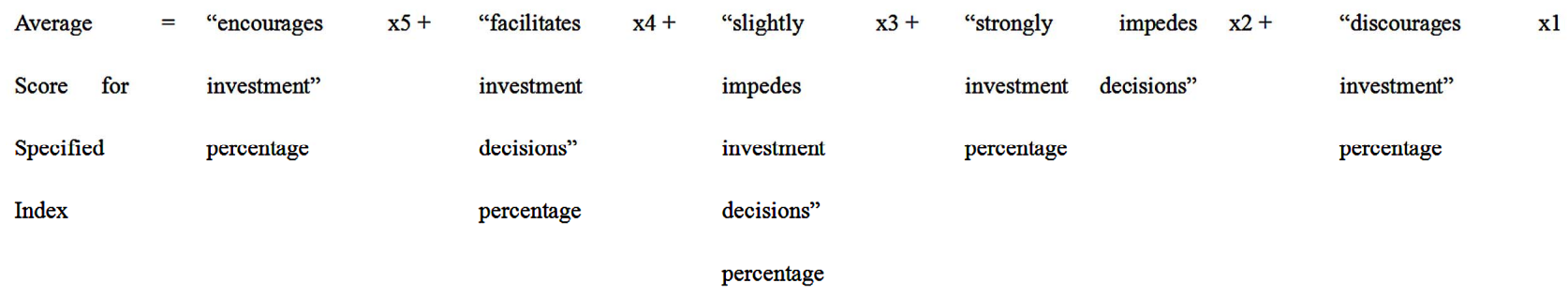

Figure 1.

The equation for integrating independent variables

market in these countries primarily depicts non-discriminating state-control where granted property rights over oil fields are refused to foreign energy enterprises. Under this condition, from 2003 to 2010, Chinese energy enterprises made 74 investments in the Middle East with 146 rights of oil fields or construction work (Table 2 and Figure 2), primarily comprised from property rights over oil fields, extraction, investigation, and supply of oil or gas.

Only China's Middle Eastern investments in Qatar, UAE, and Oman were higher than global averages for the region. However, the performance of each index and total performance in Iraq and Iran were substantially below average. Chinese energy enterprises' investments in Iraq and Iran comprised 28\% of their total Middle Eastern investment. Additionally, most Chinese investments were made in Syria, where the economic performance was below the global average. According to this distribution scene, the first sub-hypothesis proposed may, partially, be testified.

The number of investments from Chinese energy enterprises in each country reflected China's regional difficulties (Table 3). The majority of investments went to Syria and Iran, which totalled $56.7 \%$ of total investments. These nations are isolated internationally for political and human rights issues. Although the basic energy-related infrastructures in these countries are insufficient compared with other regional countries, they exercise absolute control over domestic oil fields and are well-equipped. The investment scheme made in Syria and Iran by Chinese energy corporations highlighted China's investment targets and preferences.

China's initial investment in Syria involved cooperation between Chinese energy enterprises and local government and enterprises. The Gbeibe oil fields exploited joint-investment from the CNPC, the Syrian Ministry of Oil, and Syria National Petroleum Corporation. Another investment path was cooperation with foreign investors, as seen by the merger of Al Furat Production Company's stakeholders' right to cooperate with the CNPC and the India Petroleum Natural Gas Corporation in 2005. However, from 2009, mergers and acquisitions with foreign corporations became the principal investment path for Chinese enterprises. In 2008, the CNPC merged with Canadian Tanganyika Oil and acquired eight property rights over oil fields. In 2010, CNPC merged with a subsidiary of Shell in Syria, and acquired 40 oil fields.

Conversely, the investments from Chinese energy corporations in Iran emphasized mutual cooperation between governments, including state-owned corporations. Reduced Western investment in Iran may also facilitate Chinese enterprises' cooperation with host countries. However, a more critical difference is that Chinese energy corporations' investments in Iran principally focused on basic infrastructure. In the North Pars oil field, investment from the CNPC expedited liquefied natural gas factories and transportation facilities for liquefied natural gas. In 2009, the CNPC promised Iran US\$6.5 billion in investment for refining equipment. Hence, it can be suggested that a mutually beneficial relationship existed between Chinese energy corporations and the Iranian government. This enabled Iran to obtain the basic infrastructure needed for its oil refineries, while at the same time granted China with the rights associated with Iranian oil and gas fields.

\section{Central Asia}

Trans-national energy enterprises were only able to increase their energy-related investments in Central Asia after the collapse of the USSR. Cooperation and dialog between Shanghai and the five countries of former Soviet Central Asia (Kazakhstan, Kyrgyzstan, Uzbekistan, Tajikistan and Turkmenistan), and the Shanghai cooperation organization, strengthened mutual political trust between Central Asia and China. Additionally, no competitive relations among oil or gas exporting countries existed, and therefore facilitated intensive energy-related cooperation between these countries (Nincic, 2009). Compared with the Middle East where unfavourable conditions arose due to host country interference, interference by Central Asian countries in energy markets proved beneficial to China.

Table 4 and Figure 3 show how, from 2003 to 2010, a total of 43 investment projects were made in Central Asia by Chinese energy corporations, which included 160 right of oil fields or construction work. These were principally rights of investigation, extraction, property rights of oil fields, and supply of oil or gas.

Investing patterns were credited in facilitating Chinese energy corporations' acquisition of 160 rights in 43 investment projects. The main approach for Chinese energy corporations' regional investments was the establishment of new energy corporations through joint-investment with host country's enterprises and the merger with third-country enterprises. From 2003 to 2010, Chinese energy corporations acquired 39 rights through seven merger and acquisition projects. Five joint ventures were established, and 84 rights obtained, through cooperation with state-owned energy enterprises in Kazakhstan and Uzbekistan, respectively. The merger and acquisition project completed by the CNPC, in 2009, is the best example of this investment pattern. The CNPC and Khazak National Petroleum and Natural Gas Corporation, co-financed Mangistau Investments B.V. in the Netherlands. Mangistau Investments

B.V. purchased all the properties of Mangistau Munai Gas (MMG) and acquired 15 rights of investigation and extraction each from the Kalamkas and Zhetybai regions.

The CNPC's four oil-gas pipe construction projects in Ka- 
Table 2.

Chinese energy enterprises’ investment in the Middle East between 2003 and 2010.

\begin{tabular}{|c|c|c|c|c|c|c|c|c|}
\hline \multirow[b]{2}{*}{ Country } & \multicolumn{3}{|c|}{ Right of oil field } & \multirow{2}{*}{$\begin{array}{l}\text { Oil/gas } \\
\text { supply }\end{array}$} & \multicolumn{3}{|c|}{ Basic infrastructure } & \multirow[b]{2}{*}{ Total } \\
\hline & $\begin{array}{c}\text { Right of } \\
\text { investigation }\end{array}$ & $\begin{array}{l}\text { Right of } \\
\text { extraction }\end{array}$ & $\begin{array}{l}\text { Property right } \\
\text { of oil field }\end{array}$ & & $\begin{array}{l}\text { Refinement of } \\
\text { crude oil }\end{array}$ & $\begin{array}{l}\text { Store of } \\
\text { crude oil }\end{array}$ & $\begin{array}{c}\text { Transport of } \\
\text { crude oil }\end{array}$ & \\
\hline Qatar & 0 & 0 & 0 & 1 & 0 & 0 & 0 & 1 \\
\hline Iraq & 2 & 6 & 1 & 0 & 0 & 1 & 0 & 10 \\
\hline Iran & 4 & 11 & 5 & 6 & 5 & 0 & 0 & 31 \\
\hline Saudi Arabia & 9 & 1 & 1 & 5 & 6 & 0 & 0 & 22 \\
\hline Azerbaijan & 0 & 0 & 4 & 0 & 0 & 0 & 0 & 4 \\
\hline UAE & 0 & 0 & 1 & 0 & 0 & 0 & 1 & 2 \\
\hline Oman & 2 & 1 & 0 & 4 & 0 & 0 & 0 & 7 \\
\hline Kuwait & 0 & 4 & 0 & 1 & 0 & 0 & 0 & 5 \\
\hline Syria & 2 & 0 & 50 & 1 & 1 & 0 & 0 & 54 \\
\hline Yemen & 5 & 4 & 1 & 0 & 0 & 0 & 0 & 10 \\
\hline Total & 24 & 27 & 63 & 18 & 12 & 1 & 1 & 146 \\
\hline
\end{tabular}

Table 3.

Investigation result of Chinese investments in Middle Eastern Nations from Global Energy Investigation Result Report.

\begin{tabular}{|c|c|c|c|c|c|c|c|c|c|}
\hline Country & Finance & $\begin{array}{l}\text { Tax } \\
\text { regulations }\end{array}$ & $\begin{array}{l}\text { Price of } \\
\text { natural gas }\end{array}$ & $\begin{array}{l}\text { Price paid for rules } \\
\text { compromised }\end{array}$ & $\begin{array}{l}\text { Uncertainties of } \\
\text { rules }\end{array}$ & $\begin{array}{l}\text { Environmental } \\
\text { rules }\end{array}$ & $\begin{array}{c}\text { Local } \\
\text { production } \\
\text { facilities }\end{array}$ & $\begin{array}{l}\text { Trade } \\
\text { rules }\end{array}$ & $\begin{array}{l}\text { Labour } \\
\text { regulations }\end{array}$ \\
\hline $\begin{array}{l}\text { Average } \\
\text { (shown in } \\
\text { Report) }\end{array}$ & 3.862 & 3.863 & 3.73 & 3.641 & 3.643 & 3.76 & 3.781 & 3.852 & 3.787 \\
\hline Qatar & 4.04 & 4.06 & 3.86 & 4.00 & 4.11 & 4.01 & 3.84 & 4.16 & 3.90 \\
\hline Iraq & 3.01 & 3.07 & 2.97 & 3.26 & 2.69 & 3.81 & 3.30 & 3.38 & 3.47 \\
\hline Iran & 2.22 & 2.56 & 2.97 & 3.26 & 2.69 & 3.81 & 3.30 & 3.38 & 3.47 \\
\hline Saudi Arabia & N/A & N/A & N/A & N/A & N/A & N/A & N/A & N/A & N/A \\
\hline Azerbaijan & 3.86 & 3.76 & 3.47 & 3.48 & 3.50 & 3.85 & 3.59 & 3.71 & 3.70 \\
\hline UAE & 3.80 & 4.05 & 3.75 & 3.84 & 3.85 & 3.89 & 3.93 & 4.15 & 3.87 \\
\hline Oman & 3.81 & 3.69 & 3.71 & 3.73 & 3.82 & 3.83 & 3.74 & 3.88 & 3.55 \\
\hline Kuwait & 3.16 & 3.54 & 3.49 & 3.42 & 3.49 & 3.89 & 3.36 & 3.60 & 3.49 \\
\hline Syria & 3.49 & 3.45 & 3.38 & 3.45 & 3.33 & 3.89 & 3.38 & 3.35 & 3.30 \\
\hline Yemen & 3.55 & 3.65 & 3.02 & 3.52 & 3.45 & 3.93 & 3.48 & 3.70 & 3.24 \\
\hline Country & $\begin{array}{l}\text { Public basic } \\
\text { infrastructure }\end{array}$ & $\begin{array}{l}\text { Business } \\
\text { infrastructure }\end{array}$ & $\begin{array}{l}\text { Geologic } \\
\text { database }\end{array}$ & Labour capabilities & Land disputes & $\begin{array}{l}\text { Political } \\
\text { stability }\end{array}$ & Security & & Total \\
\hline $\begin{array}{l}\text { Average } \\
\text { (shown in } \\
\text { Report) }\end{array}$ & 3.761 & 3.837 & 3.992 & 3.921 & 3.993 & 3.889 & 4.084 & & 61.40 \\
\hline Qatar & 4.26 & 4.25 & 4.04 & 3.80 & 4.16 & 4.27 & 4.32 & & 65.08 \\
\hline Iraq & 2.71 & 2.99 & 3.52 & 3.31 & 3.23 & 2.29 & 2.51 & & 49.52 \\
\hline Iran & 2.99 & 2.95 & 3.37 & 3.37 & 3.21 & 2.75 & 3.29 & & 46.34 \\
\hline Saudi Arabia & N/A & N/A & N/A & N/A & N/A & N/A & N/A & & N/A \\
\hline Azerbaijan & 3.66 & 3.29 & 3.45 & 3.82 & 3.8 & 3.43 & 3.74 & & 58.11 \\
\hline UAE & 4.24 & 4.31 & 3.99 & 4.06 & 4.34 & 4.37 & 4.28 & & 64.72 \\
\hline Oman & 3.76 & 3.79 & 4.04 & 3.91 & 4.29 & 4.13 & 4.29 & & 61.97 \\
\hline Kuwait & 3.75 & 3.72 & 3.81 & 3.78 & 3.97 & 3.90 & 4.05 & & 58.42 \\
\hline Syria & 3.29 & 3.26 & 3.36 & 3.62 & 3.63 & 3.36 & 3.59 & & 55.13 \\
\hline Yemen & 2.84 & 3.11 & 3.46 & 3.4 & 3.43 & 2.81 & 2.95 & & 53.54 \\
\hline
\end{tabular}


Table 4.

Chinese energy enterprises’ investment in Central Asia between 2003 and 2010.

\begin{tabular}{|c|c|c|c|c|c|c|c|c|}
\hline \multirow[b]{2}{*}{ Country } & \multicolumn{3}{|c|}{ Right of oil field } & \multirow{2}{*}{$\begin{array}{l}\text { Oil/gas } \\
\text { supply }\end{array}$} & \multicolumn{3}{|c|}{ Basic infrastructure } & \multirow[b]{2}{*}{ Total } \\
\hline & $\begin{array}{c}\text { Right of } \\
\text { investigation }\end{array}$ & $\begin{array}{l}\text { Right of } \\
\text { extraction }\end{array}$ & $\begin{array}{l}\text { Property right of } \\
\text { oil field }\end{array}$ & & $\begin{array}{l}\text { Refinement of } \\
\text { crude oil }\end{array}$ & $\begin{array}{l}\text { Store of crude } \\
\text { oil }\end{array}$ & $\begin{array}{c}\text { Transport of } \\
\text { crude oil }\end{array}$ & \\
\hline Kazakhstan & 30 & 21 & 25 & 2 & 2 & 0 & 3 & 83 \\
\hline Turkmenistan & 2 & 5 & 1 & 3 & 0 & 0 & 1 & 12 \\
\hline Uzbekistan & 31 & 27 & 5 & 2 & 0 & 0 & 0 & 65 \\
\hline Total & 63 & 53 & 31 & 7 & 2 & 0 & 4 & 160 \\
\hline
\end{tabular}

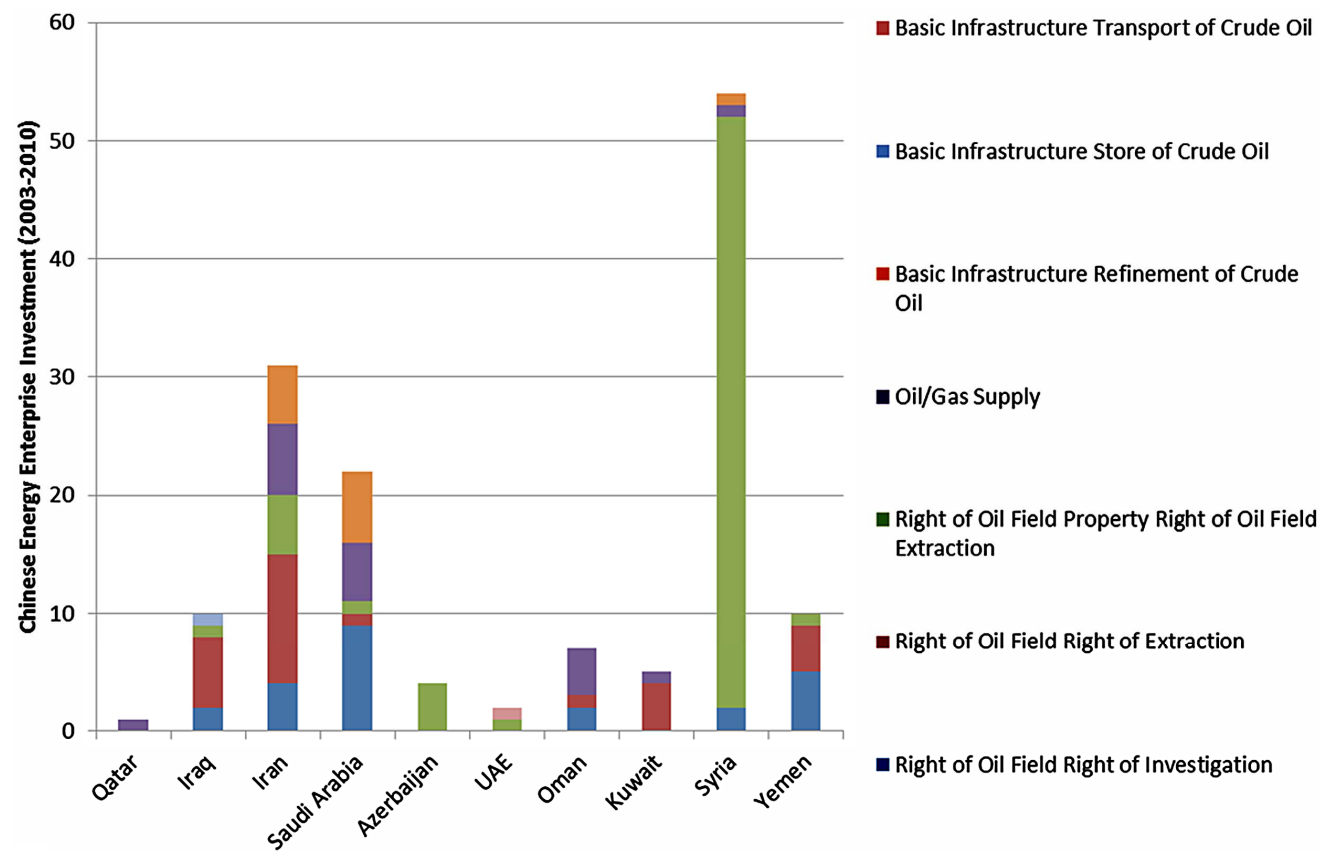

Figure 2.

Chinese energy enterprises' investment in the Middle East between 2003 and 2010.

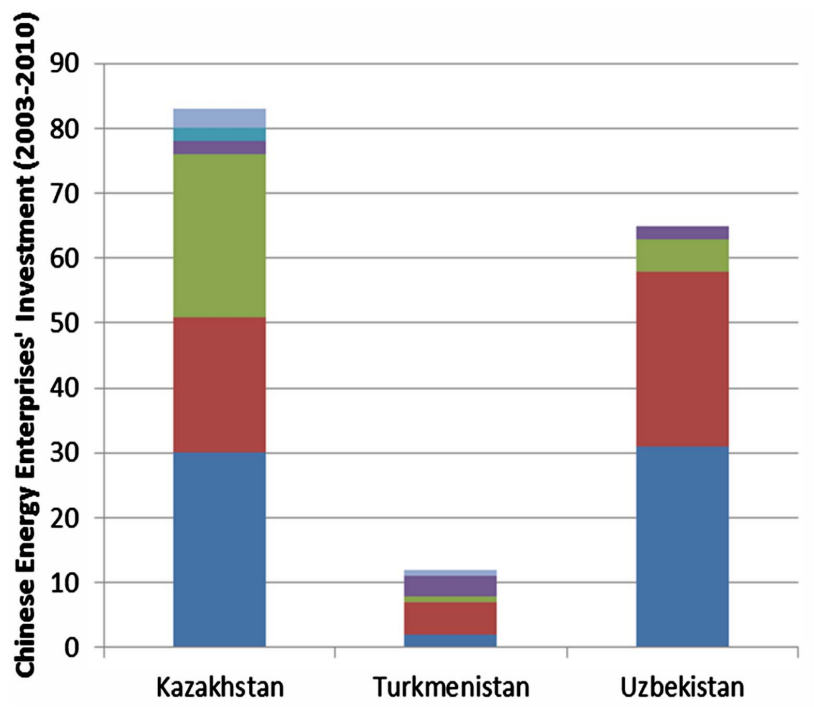

— Basic Infrastructure Transport of Crude Oil

- Basic Infrastructure Store of Crude Oil

- Basic Infrastructure Refinement of Crude Oil

- Oil/Gas Supply

- Right of Oil Field Property Right of Oil Field Extraction

- Right of Oil Field Right of Extraction

Figure 3.

Chinese energy enterprises’ investment in Central Asia between 2003 and 2010. 
zakhstan and Turkmenistan signalled another important characteristic of China's regional energy diplomacy. These four construction projects built three resource pipelines linked to China through Xinjiang, and connected directly to the west-east network. The first pipeline connected Atyrau, Western Kazakhstan, with Alashan, Xinjiang. The second connected Almaty with Korla, Xinjiang, and the third connected the Amu River with Huoerguosi, Xinjiang.

Notably, managers from trans-national energy enterprises appraised poorly the three Central Asian countries. In a report covering 2007 to 2010, the economic performance of these three countries lagged behind the global average. Environmental regulation in Kazakhstan and Uzbekistan only slightly exceeded the global average. The remaining 15 indices fell below their respective global averages (Table 5). The overall performance of Turkmenistan and business infrastructures in Kazakhstan and Uzbekistan ranked among the lowest globally.

\section{Africa}

Africa constitutes a major investment destination for many trans-national energy corporations, due to the incapability of host countries to refuse foreign corporate capital (African Development Bank and the African Union, 2009). Table 6 and Figure 4 show how, from 2003 to 2010, 71 investment projects were initiated by Chinese energy corporations in 16 African countries. These led to the acquisition of 165 rights of oil fields or construction work, of which, 112 , or $68.3 \%$ of total rights, were the right of investigation and extraction.

The investment scheme by Chinese energy corporations in Africa reflected Africa's relative development weakness in the international energy market. Unlike Middle Eastern nations who have significant control over their oil fields or the three Central Asian countries, the African energy market was the closest conceptually to a perfect market. Due to this relative regional development weakness, Chinese energy corporations' investments depicted prominent neo-mercantilist concepts, especially in investment patterns, competition, and cooperation with European/American energy enterprises.

Firstly, Chinese energy corporations often obtained property rights to oil fields or supply of oil or gas through investments in basic energy-related infrastructure. In most cases with Chad as an exception, China built oil refineries in countries with extensive oil fields or in countries where China imported crude oil. Sudan, Nigeria, and Algeria contained large oil fields, while Angola and Niger imported oil from China. Nigeria and Niger acted as examples of "construction work for oil and gas". The CNPC purchased priority development rights in the OPL721, 732, 281, and 471 regions of Nigeria in May, 2006. Subsequently, the Chinese government promised to buy the Kaduna oil refinery in Nigeria, for US \$2 billion. Furthermore, the CNPC's construction work on oil refineries in Niger in November, 2008, propagated a three-year contract with the right of extraction in the Agedem region.

Secondly, Western energy enterprises had large investments in West Africa, particularly in Nigeria and Gabon. Until 2008, China only obtained (Angevine \& Cameron, 2007) rights in these respective countries. Following the global financial crisis, however, China obtained eight rights of investigation and 17 rights associated with nine oil fields, through the merger and acquisition of Addax Petroleum, in 2009.

Table 7 shows that the economic evaluations of China's investments in Africa were lower than the global average. The political stability and security indexes of Niger, Algeria, Nigeria, Democratic Republic of Congo, Sudan, and Chad were far below the average. The economic performance of Nigeria, the recipient of most Chinese investments, ranked lowest.

\section{Why Mercantilism?}

\section{Testing Sub-Hypothesis \#1}

This study utilized information from Tables $\mathbf{2}$ to $\mathbf{6}$ and conducted a Pearson Correlation Analysis; the results are shown in

Table 5.

Investigation result of Chinese investments in Central Asian Nations from Global Energy Investigation Result Report.

\begin{tabular}{|c|c|c|c|c|c|c|c|c|c|}
\hline Country & Finance & $\begin{array}{l}\text { Tax } \\
\text { regulations }\end{array}$ & $\begin{array}{c}\text { Price of } \\
\text { natural gas }\end{array}$ & $\begin{array}{l}\text { Price paid for } \\
\quad \text { rules } \\
\text { compromised }\end{array}$ & $\begin{array}{c}\text { Uncertainties of } \\
\text { rules }\end{array}$ & $\begin{array}{l}\text { Environmental } \\
\text { rules }\end{array}$ & $\begin{array}{l}\text { Local production } \\
\text { facilities }\end{array}$ & Trade rules & $\begin{array}{l}\text { S } \quad \begin{array}{l}\text { Labour } \\
\text { regulations }\end{array}\end{array}$ \\
\hline Kazakhstan & 3.39 & 3.45 & 3.12 & 3.08 & 2.85 & 3.72 & 3.47 & 3.29 & 3.32 \\
\hline Turkmenistan & 2.99 & 2.95 & 3.20 & 2.81 & 2.79 & 3.51 & 3.22 & 3.22 & 3.17 \\
\hline Uzbekistan & 3.41 & 3.48 & 3.39 & 3.11 & 2.80 & 3.96 & 3.48 & 3.48 & 3.30 \\
\hline Country & $\begin{array}{l}\text { Public basic } \\
\text { infrastructure }\end{array}$ & $\begin{array}{c}\text { Business } \\
\text { infrastructure }\end{array}$ & $\begin{array}{l}\text { Geologic } \\
\text { database }\end{array}$ & $\begin{array}{c}\text { Labour } \\
\text { capabilities }\end{array}$ & Land disputes & Political stability & Security & \multicolumn{2}{|c|}{ Total } \\
\hline $\begin{array}{l}\text { Average } \\
\text { (shown in } \\
\text { Report) }\end{array}$ & 3.76 & 3.84 & 3.99 & 3.92 & 3.99 & 3.89 & 4.08 & \multicolumn{2}{|c|}{61.40} \\
\hline Turkmenistan & 3.12 & 2.78 & 3.20 & 3.57 & 3.81 & 3.22 & 3.06 & \multicolumn{2}{|c|}{52.45} \\
\hline Kazakhstan & 2.99 & 3.08 & 3.33 & 3.68 & 3.86 & 3.45 & 3.20 & \multicolumn{2}{|c|}{51.46} \\
\hline Uzbekistan & 3.39 & 2.95 & 3.18 & 3.72 & 3.85 & 3.37 & 3.42 & \multicolumn{2}{|c|}{54.28} \\
\hline
\end{tabular}


Table 6.

Chinese energy enterprises' investment in Africa between 2003 and 2010.

\begin{tabular}{|c|c|c|c|c|c|c|c|c|}
\hline \multirow[b]{2}{*}{ Country } & \multicolumn{3}{|c|}{ Right of oil field } & \multirow{2}{*}{$\begin{array}{l}\text { Oil/gas } \\
\text { supply }\end{array}$} & \multicolumn{3}{|c|}{ Basic infrastructure } & \multirow[b]{2}{*}{ Tota } \\
\hline & $\begin{array}{c}\text { Right of } \\
\text { investigation }\end{array}$ & $\begin{array}{l}\text { Right of } \\
\text { extraction }\end{array}$ & $\begin{array}{l}\text { Property right } \\
\text { of oil field }\end{array}$ & & $\begin{array}{l}\text { Refinement of } \\
\text { crude oil }\end{array}$ & $\begin{array}{l}\text { Store of crude } \\
\text { oil }\end{array}$ & $\begin{array}{l}\text { Transport of } \\
\text { crude oil }\end{array}$ & \\
\hline Sudan & 1 & 1 & 5 & 0 & 0 & 0 & 2 & 9 \\
\hline Algeria & 3 & 3 & 2 & 1 & 3 & 1 & 0 & 13 \\
\hline Libya & 1 & 0 & 0 & 1 & 0 & 0 & 2 & 4 \\
\hline Nigeria & 11 & 12 & 4 & 1 & 0 & 0 & 0 & 28 \\
\hline Gabon & 8 & 3 & 6 & 1 & 0 & 0 & 0 & 18 \\
\hline Tunisia & 14 & 14 & 1 & 0 & 0 & 0 & 0 & 29 \\
\hline Mauritania & 6 & 4 & 1 & 1 & 0 & 0 & 0 & 12 \\
\hline Morocco & 3 & 0 & 0 & 0 & 0 & 0 & 0 & 3 \\
\hline Kenya & 6 & 0 & 0 & 0 & 0 & 0 & 4 & 10 \\
\hline Angola & 4 & 1 & 5 & 0 & 1 & 0 & 0 & 11 \\
\hline Somalia & 1 & 0 & 0 & 0 & 0 & 0 & 0 & 1 \\
\hline Niger & 2 & 2 & 0 & 0 & 2 & 0 & 2 & 8 \\
\hline Equatorial Guinea & 1 & 1 & 0 & 0 & 0 & 0 & 0 & 2 \\
\hline Cameroon & 2 & 0 & 0 & 0 & 0 & 0 & 0 & 2 \\
\hline Chad & 3 & 3 & 3 & 0 & 2 & 0 & 1 & 12 \\
\hline Republic of Congo & 2 & 0 & 0 & 0 & 0 & 0 & 0 & 2 \\
\hline Total & 68 & 44 & 27 & 5 & 8 & 1 & 11 & 164 \\
\hline
\end{tabular}

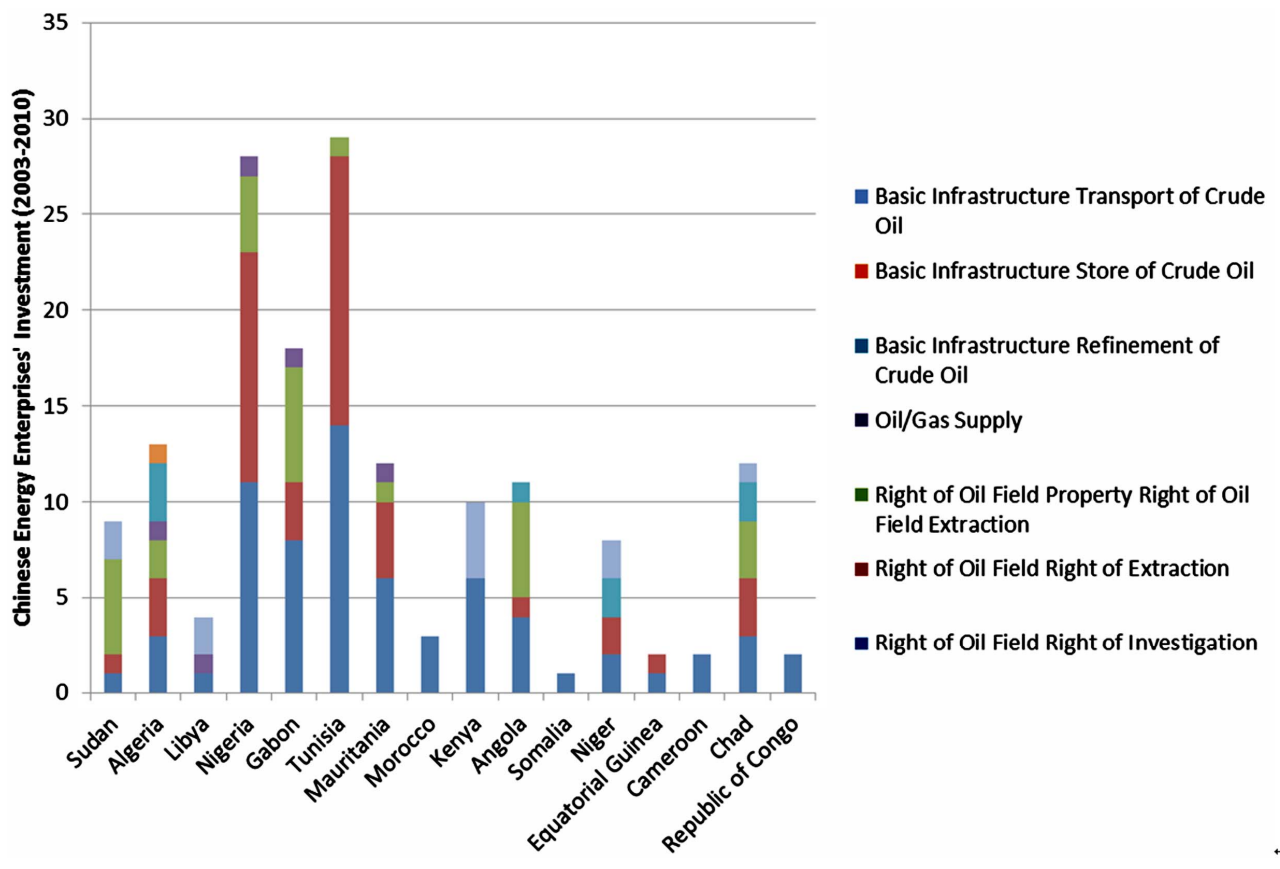

Figure 4.

Chinese energy enterprises' investment in Africa between 2003 and 2010. 
Table 7.

Investigation result of Chinese investments in African Nations from Global Energy Investigation Result Report.

\begin{tabular}{|c|c|c|c|c|c|c|c|c|c|}
\hline Country & Finance & $\begin{array}{c}\text { Tax } \\
\text { regulations }\end{array}$ & $\begin{array}{c}\text { Price of } \\
\text { natural gas }\end{array}$ & $\begin{array}{l}\text { Price paid for } \\
\text { rules } \\
\text { compromised }\end{array}$ & $\begin{array}{l}\text { Uncertainties of } \\
\text { rules }\end{array}$ & $\begin{array}{l}\text { Environmental } \\
\text { rules }\end{array}$ & $\begin{array}{c}\text { Local } \\
\text { production } \\
\text { facilities }\end{array}$ & $\begin{array}{l}\text { Trade } \\
\text { rules }\end{array}$ & $\begin{array}{l}\text { Labour } \\
\text { regulations }\end{array}$ \\
\hline $\begin{array}{l}\text { Average (shown in } \\
\text { Report) }\end{array}$ & 3.86 & 3.86 & 3.73 & 3.64 & 3.64 & 3.76 & 3.78 & 3.85 & 3.79 \\
\hline Gabon & 3.78 & 3.76 & 3.40 & 3.55 & 3.50 & 3.80 & 3.70 & 3.70 & 3.53 \\
\hline Niger & 3.39 & 3.55 & 3.65 & 3.33 & 3.07 & 3.70 & 3.41 & 3.07 & 3.26 \\
\hline Angola & 3.78 & 3.69 & 3.23 & 3.55 & 3.60 & 4.07 & 3.46 & 3.92 & 3.58 \\
\hline Libya & 3.10 & 3.25 & 3.59 & 3.27 & 3.37 & 3.99 & 3.35 & 3.51 & 3.47 \\
\hline Equatorial Guinea & 3.32 & 3.55 & 3.49 & 3.31 & 3.34 & 3.77 & 3.61 & 3.67 & 3.50 \\
\hline Nigeria & 3.18 & 3.14 & 3.15 & 3.13 & 2.98 & 3.65 & 3.04 & 3.45 & 2.98 \\
\hline Kenya & N/A & N/A & N/A & N/A & N/A & N/A & N/A & N/A & N/A \\
\hline Algeria & 2.92 & 3.2 & 3.36 & 3.28 & 3.13 & 3.96 & 3.54 & 3.51 & 3.58 \\
\hline Chad & 3.48 & 3.54 & 3.11 & 3.35 & 3.36 & 4.10 & 3.48 & 3.28 & 3.89 \\
\hline Tunisia & 3.62 & 3.55 & 3.79 & 3.57 & 3.42 & 3.78 & 3.25 & 3.41 & 3.53 \\
\hline Mauritania & N/A & N/A & N/A & N/A & N/A & N/A & N/A & N/A & N/A \\
\hline Republic of Congo & 3.51 & 3.49 & 3.29 & 3.44 & 3.55 & 3.95 & 3.32 & 3.45 & 3.49 \\
\hline Somalia & N/A & N/A & N/A & N/A & N/A & N/A & N/A & N/A & N/A \\
\hline Cameroon & 3.84 & 3.42 & 3.22 & 3.69 & 3.45 & 3.93 & 3.93 & 3.83 & 3.68 \\
\hline Morocco & 4.00 & 3.89 & 3.49 & 3.85 & 4.03 & 4.02 & 3.85 & 3.58 & 3.85 \\
\hline Sudan & 3.10 & 3.18 & 3.38 & 3.15 & 2.98 & 3.90 & 3.31 & 3.33 & 3.62 \\
\hline Country & $\begin{array}{l}\text { Public basic } \\
\text { infrastructure }\end{array}$ & $\begin{array}{l}\text { Business } \\
\text { infrastructure }\end{array}$ & $\begin{array}{l}\text { Geologic } \\
\text { database }\end{array}$ & $\begin{array}{l}\text { Labour } \\
\text { capabilities }\end{array}$ & Land disputes & $\begin{array}{l}\text { Political } \\
\text { stability }\end{array}$ & Security & & Total \\
\hline $\begin{array}{l}\text { Average(shown in } \\
\text { Report) }\end{array}$ & 3.76 & 3.84 & 3.99 & 3.92 & 3.99 & 3.89 & 4.08 & & 61.40 \\
\hline Gabon & 3.15 & 3.39 & 3.52 & 3.59 & 3.66 & 3.44 & 3.61 & & 57.08 \\
\hline Niger & 2.46 & 2.65 & 3.02 & 2.89 & 2.89 & 2.76 & 3.08 & & 50.18 \\
\hline Angola & 3.00 & 3.27 & 3.67 & 3.68 & 3.93 & 3.31 & 3.59 & & 57.33 \\
\hline Libya & 3.13 & 3.12 & 3.61 & 3.99 & 4.00 & 3.58 & 3.81 & & 56.14 \\
\hline Equatorial Guinea & 2.97 & 3.15 & 3.44 & 3.28 & 3.43 & 3.07 & 3.36 & & 54.26 \\
\hline Nigeria & 2.61 & 3.14 & 3.48 & 3.19 & 2.88 & 2.33 & 2.42 & & 48.75 \\
\hline Kenya & N/A & N/A & N/A & N/A & N/A & N/A & N/A & & N/A \\
\hline Algeria & 3.43 & 3.49 & 3.66 & 3.74 & 3.87 & 2.99 & 3.08 & & 54.74 \\
\hline Chad & 2.47 & 2.50 & 3.38 & 3.54 & 2.99 & 2.28 & 2.40 & & 51.15 \\
\hline Tunisia & 3.83 & 3.83 & 3.71 & 3.75 & 4.28 & 3.53 & 3.82 & & 58.67 \\
\hline Mauritania & N/A & N/A & N/A & N/A & N/A & N/A & N/A & & N/A \\
\hline Republic of Congo & 2.86 & 3.05 & 3.19 & 3.60 & 3.53 & 3.07 & 3.11 & & 53.90 \\
\hline Somalia & N/A & N/A & N/A & N/A & N/A & N/A & N/A & & N/A \\
\hline Cameroon & 3.13 & 3.41 & 3.55 & 3.59 & 3.66 & 3.68 & 3.57 & & 57.58 \\
\hline Morocco & 3.46 & 3.56 & 3.75 & 3.92 & 3.94 & 3.97 & 4.20 & & 61.36 \\
\hline Sudan & 2.51 & 3.00 & 3.06 & 2.93 & 2.89 & 2.15 & 2.50 & & 48.99 \\
\hline
\end{tabular}

Table 8. Related data for Somalia, Kenya, Mauritania, and Saudi Arabia were excluded because such information was not provided in the secondary resources of this study. When assessing the connection between global distribution and the host country's average economic evaluation, it became obvious that the host country's investment environment was not the main variable which Chinese energy enterprises interpreted when making overseas investment decisions. Moreover, a negative correlation existed between the host country's investment environment and the basic infrastructure construction contract signed by China globally.

Table 8 shows a negative correlation between Chinese energy corporations' overseas investment and global energy enterprise's executive evaluation over the past five years. Therefore, the first sub-hypothesis revealed that Chinese energy corporations' overseas investments were not dependent on the economic logic of the enterprise level, investment costs or profitability.

Such negative correlations partially fell between 2007 and 2010 (Table 9), though the scale of this decline was indistinct 
and might be attributed to the global financial crisis. When Western enterprises were affected by the crisis, Chinese energy enterprises' investments in basic infrastructure in countries with poor economic performance dropped. The negative correlation between rights of oil fields and economic evaluation similarly declined. It was likely that the crisis weakened Western energy enterprises, and contributed to this trend. However, when comparing investment distributions from 2003 onwards, and from 2007 onwards, with the host country's economic evaluation, both distributions reflected that economic components of the enterprise were not significant factors that Chinese energy corporations considered when making overseas investment decisions.

\section{Testing Sub-Hypothesis \#2}

According to the study by Downs, many participants agreed on outreaching when overseas investment issues were raised when negotiating energy security policies. However, due to low commercial benefits, Chinese energy corporations became strongly opposed to building foreign oil pipelines (Downs, 2004). From the overseas investments of Chinese energy corporations, only 16 oil or gas foreign pipelines were built. Of these, the most important investment which best reflected the second sub-hypothesis in this study, was located in Central Asia.

A total of four pipelines were built in Central Asia by Chinese energy corporations, and were largely related to China's energy security policy of "west gas-transport east". As mentioned in China's "Ten One Five Planning”, it was vitally important to expand domestic and overseas oil or gas resource investigations and complete the construction of national pipeline networks. The objective was to complete transportation channels such that oil produced in the west could be transported east, oil produced in the north could be transported south, and gas produced in the west could be transported east (Xinhua, 2006). The CNPC cooperated with Kazakhstan in building crude oil pipelines connecting Atasu and Atyrau, Kazakhstan with Alashan, Xinjiang. Later, from 2006, construction work began on oil pipelines connecting Almaty, Kazakhstan with Korla, Xinjiang.

Of these two pipelines, the first pipeline (Atasu-AtyrauAlashan) connected with the Caspian Pipeline Consortium (CPC) network. Furthermore, the two pipelines stretched westward into Azerbaijan. To the north, the pipelines connected with far eastern oil or gas networks in Russia; and to the southeast, the pipelines connected to oil or gas fields in South/North Pars, Iran; to the southwest, the pipelines connected to oil or gas networks in the Persian Gulf (Jiang \& Sinton, 2011).

Secondly, regardless of economic or security logic, for energy net importing nations, in general, the distance between the energy production and consumption sites is proportional to the risk presented in transportation. The economic and security costs increase when more resources are devoted to security when negotiating with the host country. If the nation's energy security strategy was a motivation for Chinese energy corporation's overseas investments decisions, then, the overseas investment distribution will depict a negative correlation with transport distance.

By accounting for China's heavy reliance on oil and gas imports, this study focuses on the geographic centre of each country when measuring the linear distance between "China" (centred on Gansu at $35^{\circ} \mathrm{N}, 105^{\circ} \mathrm{E}$ ) and the host country. Table 10 shows the distance between the geographic centre of China and the 29 countries where Chinese energy corporations invested overseas. Figure 5 visualizes the ratio of investments made to geographic distance from China, for recipient countries.

Table 8.

Correlation between Chinese energy industries’ global investments and host country’s economic appraisal between 2003 and 2010.

\begin{tabular}{|c|c|c|c|c|c|c|}
\hline & $\begin{array}{c}\text { Total weight of } \\
\text { energy } \\
\text { investments }\end{array}$ & $\begin{array}{c}\text { Right of } \\
\text { investigation }\end{array}$ & $\begin{array}{l}\text { Right of } \\
\text { extraction }\end{array}$ & $\begin{array}{l}\text { Property right } \\
\text { of oil field }\end{array}$ & Oil/gas supply & Basic infrastructure \\
\hline Overall economic appraisal & -.305 & -.207 & -.353 & -.147 & -.205 & $-.534^{* *}$ \\
\hline Financial system & -.309 & -.164 & -.384 & -.112 & $-.483^{*}$ & $-.677^{* *}$ \\
\hline Taxation system & $-.415^{*}$ & -.272 & $-.438^{*}$ & -.207 & $-.472^{*}$ & $-.625^{* *}$ \\
\hline Local price for natural gas & -.221 & -.128 & -.225 & -.133 & -.184 & -.270 \\
\hline $\begin{array}{l}\text { Price paid for rules } \\
\text { compromised }\end{array}$ & $-.486^{*}$ & -.393 & $-.562^{* *}$ & -.201 & $-.535^{* *}$ & $-.646^{* *}$ \\
\hline Uncertainties of rules & $-.477^{*}$ & $-.424^{*}$ & $-.597^{* *}$ & -.190 & -.349 & $-.533^{* *}$ \\
\hline Environmental rules & $-.397^{*}$ & -.290 & $-.442^{*}$ & -.171 & $-.599^{* *}$ & $-.446^{*}$ \\
\hline Local production needs & $-.416^{*}$ & -.274 & $-.471^{*}$ & -.218 & -.371 & $-.460^{*}$ \\
\hline Trade rules & -.386 & -.201 & -.386 & -.211 & $-.483^{*}$ & $-.663^{* *}$ \\
\hline Labour employment rules & $-.536^{* *}$ & $-.424^{*}$ & $-.547^{* *}$ & -.301 & $-.482^{*}$ & -.300 \\
\hline $\begin{array}{l}\text { Local public basic } \\
\text { infrastructure }\end{array}$ & -.086 & -.058 & -.072 & -.055 & .106 & -.366 \\
\hline Business infrastructure & -.212 & -.171 & -.221 & -.106 & -.071 & $-.412^{*}$ \\
\hline $\begin{array}{l}\text { Quality of geologic } \\
\text { database }\end{array}$ & -.320 & -.259 & -.278 & -.223 & .020 & -.344 \\
\hline Labour capabilities & -.011 & .044 & -.058 & .002 & .088 & -.265 \\
\hline Land disputes & -.013 & .086 & -.013 & -.033 & .099 & -.319 \\
\hline Political stability & -.076 & -.027 & -.152 & -.017 & .088 & -.357 \\
\hline Security & -.138 & -.129 & -.221 & -.040 & .113 & -.352 \\
\hline
\end{tabular}

Note: Made by author; a single ${ }^{*}$ mark means correlation does exist; a double ${ }^{* *}$ mark means there is a high correlation. 
H.-C. YEH, C.-W. YU

Table 9.

Correlation between Chinese energy industries’ global investments and host country’s economic appraisal between 2007 and 2010.

\begin{tabular}{|c|c|c|c|c|c|c|}
\hline & $\begin{array}{l}\text { Total weight of energy } \\
\text { investments }\end{array}$ & $\begin{array}{c}\text { Right of } \\
\text { investigation }\end{array}$ & $\begin{array}{l}\text { Right of } \\
\text { extraction }\end{array}$ & $\begin{array}{l}\text { Property rights of oil } \\
\text { field }\end{array}$ & $\begin{array}{l}\text { Oil/gas } \\
\text { supply }\end{array}$ & Basic infrastructure \\
\hline Overall economic appraisal & -.217 & -.239 & -.393 & -.048 & -.108 & -.415 \\
\hline Financial system & -.244 & -.225 & $-.495^{*}$ & -.020 & -.341 & $-.561^{*}$ \\
\hline Taxation system & -.321 & -.352 & $-.559^{*}$ & -.078 & -.328 & -.400 \\
\hline Local price for natural gas & -.156 & -.225 & -.355 & -.016 & -.100 & -.102 \\
\hline Price paid for rules compromised & -.333 & -.407 & $-.595^{* *}$ & -.052 & $-.506^{*}$ & -.467 \\
\hline Uncertainties of rules & -.274 & -.337 & $-.509^{*}$ & -.050 & -.336 & -.296 \\
\hline Environmental rules & -.309 & -.428 & $-.593^{* *}$ & -.022 & $-.546^{*}$ & -.409 \\
\hline Local production needs & -.363 & -.253 & -.452 & -.174 & -.286 & -.431 \\
\hline Trade rules & -.364 & -.189 & -.443 & -.160 & -.402 & $-.703^{* *}$ \\
\hline Labour employment rules & -.398 & -.308 & -.354 & -.240 & -.374 & -.202 \\
\hline Local public basic infrastructure & -.077 & -.207 & -.239 & -.020 & .210 & -.256 \\
\hline Business infrastructure & -.189 & -.202 & -.295 & -.055 & -.111 & -.358 \\
\hline Quality of geologic database & -.288 & -.207 & -.253 & -.184 & -.090 & -.282 \\
\hline Labour capabilities & .048 & .044 & -.043 & .058 & .222 & -.269 \\
\hline Land disputes & -.022 & .006 & -.052 & -.007 & .280 & -.382 \\
\hline Political stability & -.002 & -.024 & -.129 & .040 & .225 & -.278 \\
\hline Security & -.019 & -.172 & -.236 & .071 & .208 & -.164 \\
\hline
\end{tabular}

Note: Made by author; a single ${ }^{*}$ mark means correlation does exist; a double ${ }^{* *}$ mark means there is a high correlation.

Table 10.

Distance between China's geographic centre and Chinese energy invested nations' geographic centre.

\begin{tabular}{|c|c|c|c|c|c|}
\hline Country & Geographic centre & $\begin{array}{l}\text { Distance to China's } \\
\text { geographic centre }\end{array}$ & Nation & Geographic centre & $\begin{array}{l}\text { Distance to China's } \\
\text { geographic centre }\end{array}$ \\
\hline Kazakhstan & $48^{\circ} 00^{\prime} \mathrm{N}, 68^{\circ} 00^{\prime} \mathrm{E}$ & 3365.3539 & Kenya & $1^{\circ} 00^{\prime} \mathrm{N}, 38^{\circ} 00^{\prime} \mathrm{E}$ & 7873.5629 \\
\hline Turkmenistan & $40^{\circ} 00^{\prime} \mathrm{N}, 60^{\circ} 00^{\prime} \mathrm{E}$ & 3970.6215 & Libya & $25^{\circ} 00^{\prime} \mathrm{N}, 17^{\circ} 00^{\prime} \mathrm{E}$ & 8286.1855 \\
\hline Iran & $32^{\circ} 00^{\prime} \mathrm{N}, 53^{\circ} 00^{\prime} \mathrm{E}$ & 4784.0869 & Tunisia & $34^{\circ} 00^{\prime} \mathrm{N}, 9^{\circ} 00^{\prime} \mathrm{E}$ & 8408.7468 \\
\hline Oman & $21^{\circ} 00^{\prime} \mathrm{N}, 57^{\circ} 00^{\prime} \mathrm{E}$ & 4917.0762 & Chad & $15^{\circ} 00^{\prime} \mathrm{N}, 19^{\circ} 00^{\prime} \mathrm{E}$ & 8710.7184 \\
\hline Azerbaijan & $40^{\circ} 30^{\prime} \mathrm{N}, 47^{\circ} 30^{\prime} \mathrm{E}$ & 5030.0124 & Angola & $12^{\circ} 30^{\prime} \mathrm{N}, 18^{\circ} 30^{\prime} \mathrm{E}$ & 8940.4360 \\
\hline UAE & $24^{\circ} 00^{\prime} \mathrm{N}, 54^{\circ} 00^{\prime} \mathrm{E}$ & 5035.2235 & Algeria & $28^{\circ} 00^{\prime} \mathrm{N}, 3^{\circ} 00^{\prime} \mathrm{E}$ & 9258.5833 \\
\hline Qatar & $25^{\circ} 30^{\prime} \mathrm{N}, 51^{\circ} 15^{\prime} \mathrm{E}$ & 5232.0708 & Morocco & $32^{\circ} 00^{\prime} \mathrm{N}, 5^{\circ} 00^{\prime} \mathrm{W}$ & 9595.2247 \\
\hline Iraq & $33^{\circ} 00^{\prime} \mathrm{N}, 44^{\circ} 00^{\prime} \mathrm{E}$ & 5543.7272 & Niger & $16^{\circ} 00^{\prime} \mathrm{N}, 8^{\circ} 00^{\prime} \mathrm{E}$ & 9622.1817 \\
\hline Kuwait & $29^{\circ} 30^{\prime} \mathrm{N}, 45^{\circ} 45^{\prime} \mathrm{E}$ & 5566.4982 & Nigeria & $10^{\circ} 00^{\prime} \mathrm{N}, 8^{\circ} 00^{\prime} \mathrm{E}$ & 10010.5420 \\
\hline Saudi Arabia & $25^{\circ} 00^{\prime} \mathrm{N}, 45^{\circ} 00^{\prime} \mathrm{E}$ & 5805.2351 & Republic of Congo & $1^{\circ} 00^{\prime} \mathrm{S}, 15^{\circ} 00^{\prime} \mathrm{E}$ & 10082.6020 \\
\hline Syria & $35^{\circ} 00^{\prime} \mathrm{N}, 38^{\circ} 00^{\prime} \mathrm{E}$ & 5984.4918 & Gabon & $1^{\circ} 00^{\prime} \mathrm{S}, 11^{\circ} 45^{\prime} \mathrm{E}$ & 10278.4390 \\
\hline Yemen & $15^{\circ} 00^{\prime} \mathrm{N}, 48^{\circ} 00^{\prime} \mathrm{E}$ & 6077.1710 & Equatorial Guinea & $2^{\circ} 00^{\prime} \mathrm{N}, 10^{\circ} 00^{\prime} \mathrm{E}$ & 10346.3060 \\
\hline Somalia & $10^{\circ} 00^{\prime} \mathrm{N}, 49^{\circ} 00^{\prime} \mathrm{E}$ & 6298.9660 & Mauritania & $20^{\circ} 00^{\prime} \mathrm{N}, 12^{\circ} 00^{\prime} \mathrm{W}$ & 11000.297 \\
\hline Sudan & $15^{\circ} 00^{\prime} \mathrm{N}, 30^{\circ} 00^{\prime} \mathrm{E}$ & 7716.0383 & & & \\
\hline
\end{tabular}

Note: Ratio of investment against distance from China. 


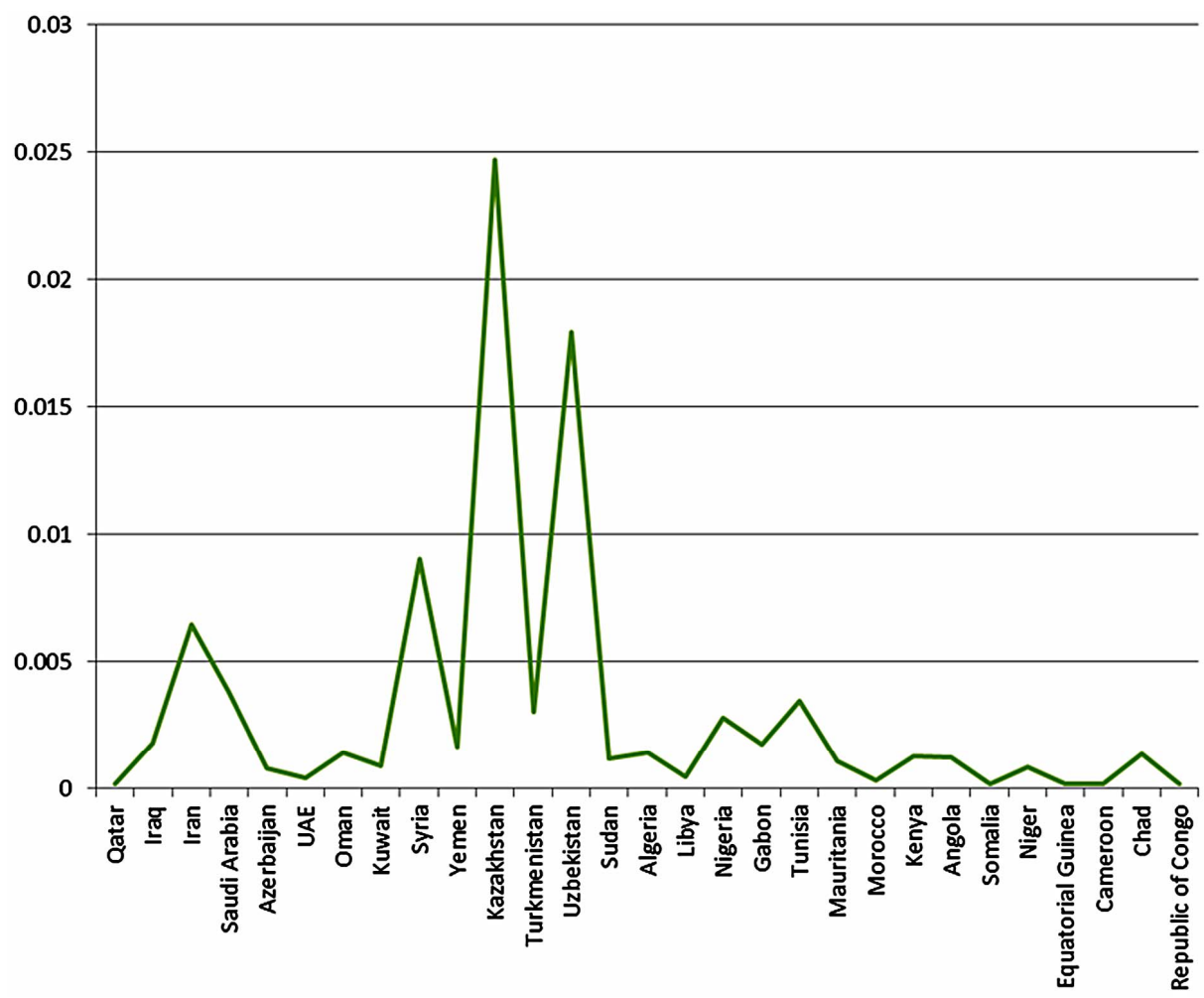

Figure 5.

Visualisation of ratio of investments made to geographic distance from China, for global recipients of Chinese energy enterprises'.

Table 11 analyzed the above data and the right of investigation, extraction, oil fields, and supply of oil or gas acquired by Chinese energy corporations overseas. The four investment categories depict inverse relations with distance for supply of oil or gas.

Finally, from 2003 to 2010, China reaffirmed its energy security policy of outreach and diversification, and emphasized its "west gas-transport east" policy and the strategy mentioned in the "Ten One Five Planning":

"Expand oil and natural gas resource investigations $\cdots$ call for equalized cooperation; mutual beneficial scenarios, expand overseas cooperative development in oil or gas resources $\cdots$ accelerate construction of oil or gas pipeline networks and related infrastructure, and gradually complete national pipeline networks; constructing west oil-transport east, north oil-transport south networks; construct secondary west-east oil pipelines, and ground transportation importing oil or gas pipelines when necessary” (Xinhua, 2006).

This official Chinese government document highlights that China's energy security policy is built with Xinjiang as the focus. This connection point was built to link overseas oil or gas supplies with domestic consumers. A national oil or gas pipeline network serves as the basis for domestic consumption which is linked to oil pipelines connected with overseas oil production. By 2007, the CNPC had signed large scale contracts for natural gas with Turkmenistan and Uzbekistan. Furthermore, China had an agreement with Turkmenistan concerning supplies of oil or gas over the next thirty years.

In cross-analyzing these three types of evidence, it is plausible that the negative correlation between the oil or gas supply and distance may be accredited to meeting China's domestic energy security policy, and explains the oil and gas supply con- tracts signed with nearby countries.

\section{Testing Sub-Hypothesis \#3}

The Effects of International Energy Market Structure on Chinese Energy Corporations Investment Strategy Tables 3, 5, and 7 show that, of all the Chinese energy corporations' investments in Central Asia, the Middle East, and Africa from 2007 to 2010, only Qatar (65.08), UAE (64.72), Oman (61.79), Morocco (61.29), and Tunisia (59.34) had averages that exceeded the average of all countries in the same period (excluding Kenya, Saudi Arabia, and Somalia). The phenomenon signalled that economic profits or cost consideration was not influential in overseas investment decisions. However, it is believed that the recent development of Chinese energy corporations in the international energy market might have also contributed to such phenomenon.

While China established its energy security policy through outreach and diversification (Table 12 and Figure 6), in 2004, the ratio of global oil exports to China was rather low. This distribution suggested that, Chinese energy corporations faced difficulties in the international energy market, during the initial stages of outreaching.

If the third sub-hypothesis is affirmable, and associated with mercantilism, then the current government should prioritize aiding energy corporations through outreach. For the government, it is more beneficial to invest in countries with sound, rather than weak, mutual interactions. Furthermore, government aid contributes to diplomacy and also facilitates overseas investments by energy corporations. Moreover, since Western enterprises invested relatively less in these countries, then entry barriers for Chinese enterprises are reduced.

The relationship between these oil producing countries and 
Table 11.

Correlation between distance and Chinese foreign investment categories.

\begin{tabular}{cccccc}
\hline & Right of investigation & Right of extraction & Property right of oil field & Oil/gas supply & Total \\
\hline $\begin{array}{c}\text { Distance to China's } \\
\text { geographic centre }\end{array}$ & -.274 & -.362 & -.243 & $-.474^{*}$ & $-.395^{*}$ \\
\hline
\end{tabular}

Source of Data: Made by author according to data listed in Tables 2-7; a single ${ }^{*}$ mark means correlation does exist; a double ${ }^{* *}$ mark means there is a high correlation. Investment.

Table 12.

Oil export states' export destination and quantity in 2004 (in ten million barrels).

\begin{tabular}{|c|c|c|c|c|c|c|c|}
\hline Destination & United States & Canada & Mexico & Central/South America & Europe & $\begin{array}{l}\text { Former Soviet } \\
\text { Union }\end{array}$ & $\begin{array}{c}\text { Australia/Asian } \\
\text { Region }\end{array}$ \\
\hline $\begin{array}{l}\text { Total amount } \\
\text { exported to China }\end{array}$ & .7 & 0 & 0 & 4.1 & 2.6 & 18 & 2.2 \\
\hline $\begin{array}{l}\text { Amount of global } \\
\text { export }\end{array}$ & 47.6 & 106.2 & 106.2 & 159.3 & 97.4 & 318.9 & 11 \\
\hline \multirow[t]{2}{*}{$\begin{array}{c}\text { Amount exported to } \\
\text { China } \\
\text { (in percentage) }\end{array}$} & $1.47 \%$ & $0 \%$ & $0 \%$ & $2.57 \%$ & $2.67 \%$ & $5.64 \%$ & $20 \%$ \\
\hline & $\begin{array}{c}\text { Others in } \\
\text { Asia Pacific Region }\end{array}$ & North Africa & $\begin{array}{l}\text { East/South } \\
\text { Africa }\end{array}$ & Middle East & Japan & West Africa & Other Regions \\
\hline $\begin{array}{l}\text { Total amount } \\
\text { exported to China }\end{array}$ & 40 & 2.1 & 5.8 & 62.8 & 2.1 & 27.5 & .5 \\
\hline $\begin{array}{l}\text { Amount of global } \\
\text { Export }\end{array}$ & 117.1 & 144.5 & 12.2 & 975.2 & 3.8 & 201.9 & 63.7 \\
\hline $\begin{array}{c}\text { Amount exported to } \\
\text { China } \\
\text { (percentage wise) }\end{array}$ & $34.16 \%$ & $1.45 \%$ & $47.54 \%$ & $6.44 \%$ & $55.26 \%$ & $13.62 \%$ & $.785 \%$ \\
\hline
\end{tabular}

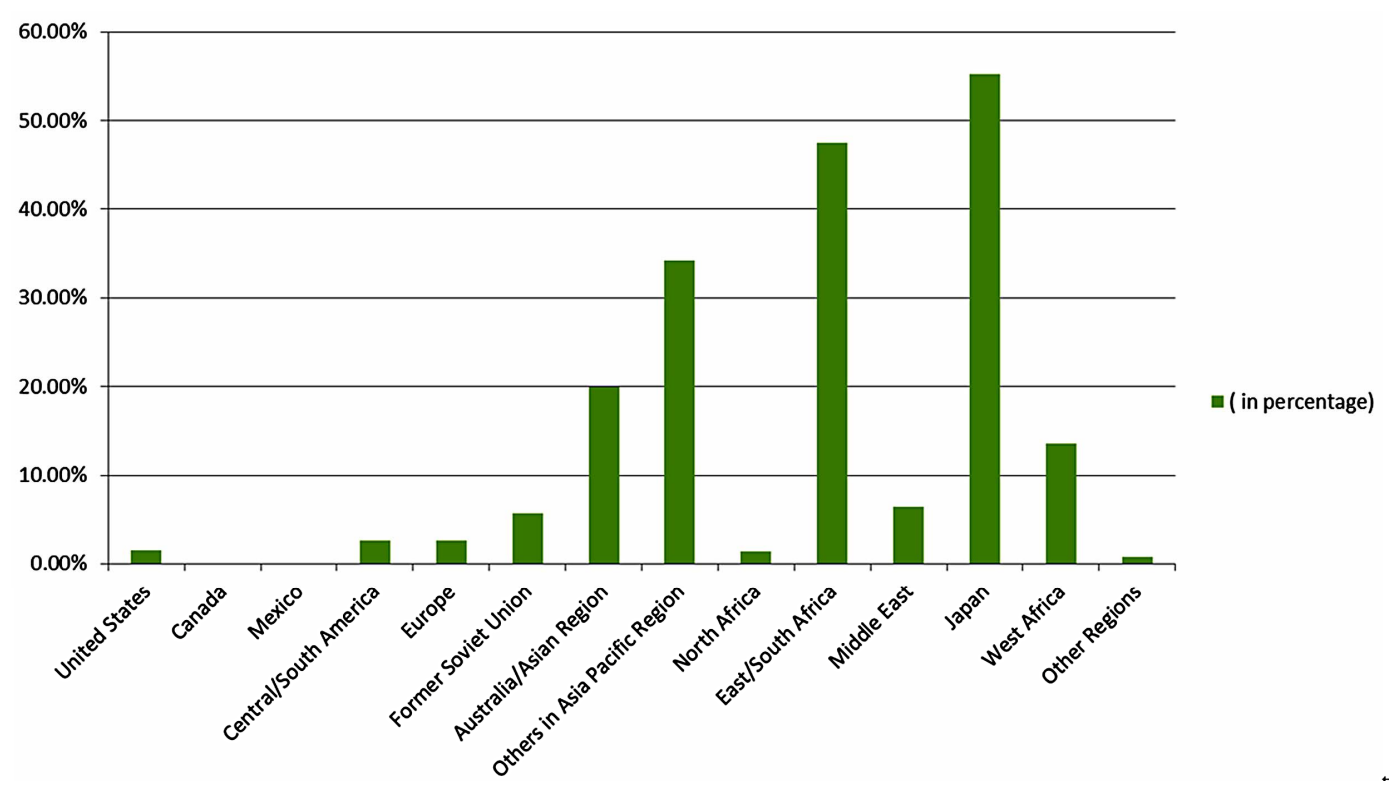

Figure 6.

Percentage total exports from oil exporting states to China, in 2004.

China roughly subdivides into two categories: first, positive interaction between China and the oil producing country; the countries of Central Asia have solid records of cooperation with
China due to the Shanghai five countries and Shanghai cooperative organizations (Oresman, 2007; Fravel, 2005; Gill, 2007; Sutter, 2008). China established close military ties with Iran 
(Garver, 2006; Byman, 2001; Gill, 2007) while at the same time fostered solid friendships with Sudan, Algeria, Libya, and Syria during the Cold War (Taylor, 2004; Snow, 1995; Tull, 2006).

Another category characterized by long-term national internal conflicts and where Western energy corporations have largely avoided, includes countries like Angola and Somalia. Table 13 shows that each type of investment project made by Chinese energy corporations in these countries amounted to more than half of the total investments in Central Asia, the Middle East, and Africa. The right of oil fields, the most critical investment, accounted for $81 \%$ of total investment in these regions. Furthermore, China acquired far more right of oil fields in these countries than the remaining 19 countries. This highlighted how overseas investment by Chinese energy corporations was affected by national security and political considerations.

Secondly, a positive correlation existed between Chinese energy corporations' investment in basic regional infrastructure and the number of rights acquired (Table 14). This correlation is particularly notable in the supply of oil or gas in the Middle East and the right of oil fields in Central Asia. This distribution reflected China's relative weaknesses in the international market that necessitated investment in basic infrastructure in order to gain certain energy rights. Of all the rights, including the rights of investigation, extraction, oil fields, and the supply of oil or gas, the rights of oil fields granted the highest level of independence. Hence, in Central Asia where fewer investments were from Western enterprises, and where host countries were more pro-China, the ratio for exchanging rights of oil fields with basic infrastructure investment was the highest. Conversely, in the Middle East where the host countries held abso- lute control over the rights of oil fields, contracts on supply of oil or gas were more common.

In May 2006, the CNPC purchased the rights of investigation and priority development from four regions in Nigeria (OPL721, 732, 281, and 471). Following this, China promised to purchase the Kaduna oil refinery in Nigeria for US\$2 billion. In November 2008, the CNPC contracted the construction of oil refineries in Niger, which enabled China to obtain a three-year term of rights of extraction in the Agedem region. Furthermore, the Chinese government promised Sudan and Algeria investments for constructing and expanding oil refineries while simultaneously purchasing oil fields from these host countries.

The same phenomenon occurred in the oil field investment project between CNOOC and North Pars, Iran. CNOOC announced its resolution to build oil refineries and liquefied natural gas transportation facilities in Iran. Once the investment project in South Pars was settled, the CNPC announced its US $\$ 1.8$ billion investment for constructing a liquefied natural gas factory. Similar acts in Central Asia by China were seen to be more evident and diversified, in that besides constructing oil refineries, China signed a contract with Kazakhstan after the global financial crisis, stating that Kazakhstan agreed to the CNPC's purchase of Mangistau Munai Gas, in 2009. Additionally, such acts were seen through energy cooperation between China and Russia, Brazil, and Venezuela.

\section{Testing Sub-Hypothesis \#4}

Table 15 and Figure 7 suggest that the main investing pattern for overseas investment of Chinese energy corporations was through the merger and acquisition of foreign enterprises.

Table 13.

Chinese oil/gas investment in closely interacted nations.

\begin{tabular}{|c|c|c|c|c|c|c|c|c|}
\hline \multirow{2}{*}{ Country } & \multicolumn{3}{|c|}{ Right of oil field } & \multirow{2}{*}{$\begin{array}{l}\text { Oil/gas } \\
\text { supply }\end{array}$} & \multicolumn{3}{|c|}{ Basic infrastructure } & \multirow[b]{2}{*}{ Total } \\
\hline & $\begin{array}{c}\text { Right of } \\
\text { investigation }\end{array}$ & $\begin{array}{l}\text { Right of } \\
\text { extraction }\end{array}$ & $\begin{array}{l}\text { Property right of } \\
\text { oil field }\end{array}$ & & $\begin{array}{l}\text { Refinement of } \\
\text { crude oil }\end{array}$ & $\begin{array}{l}\text { Store of crude } \\
\text { oil }\end{array}$ & $\begin{array}{l}\text { Transport of } \\
\text { crude oil }\end{array}$ & \\
\hline Iran & 4 & 11 & 5 & 6 & 5 & 0 & 0 & 31 \\
\hline Syria & 2 & 0 & 50 & 1 & 1 & 0 & 0 & 54 \\
\hline Kazakhstan & 30 & 21 & 25 & 2 & 2 & 0 & 3 & 83 \\
\hline Turkmenistan & 2 & 5 & 1 & 3 & 0 & 0 & 1 & 12 \\
\hline Uzbekistan & 31 & 27 & 5 & 2 & 0 & 0 & 0 & 65 \\
\hline Sudan & 1 & 1 & 5 & 0 & 0 & 0 & 2 & 9 \\
\hline Algeria & 3 & 3 & 2 & 1 & 3 & 1 & 0 & 13 \\
\hline Libya & 1 & 0 & 0 & 1 & 0 & 0 & 2 & 4 \\
\hline Angola & 4 & 1 & 5 & 0 & 1 & 0 & 0 & 11 \\
\hline Somalia & 1 & 0 & 0 & 0 & 0 & 0 & 0 & 1 \\
\hline Total & 79 & 69 & 98 & 16 & 12 & 1 & 8 & 283 \\
\hline $\begin{array}{l}\text { Number of total } \\
\text { overseas investments }\end{array}$ & 155 & 124 & 121 & 30 & 22 & 2 & 16 & 470 \\
\hline $\begin{array}{l}\text { Percentage of overseas } \\
\text { investments accounted for }\end{array}$ & $50.97 \%$ & $55.65 \%$ & $80.99 \%$ & $53.33 \%$ & $54.55 \%$ & $50 \%$ & $50 \%$ & $60.21 \%$ \\
\hline
\end{tabular}

Source of Data: Made by author according to data listed in Tables 2-7. 
Table 14.

Correlation between Chinese-built basic energy infrastructures and energy rights gained.

\begin{tabular}{|c|c|c|c|c|c|}
\hline \multicolumn{6}{|c|}{ Middle East, Central Asia and Africa } \\
\hline & $\begin{array}{l}\text { Total weight of energy } \\
\text { investments }\end{array}$ & Right of investigation & Right of extraction & Property right of oil field & Oil/gas supply \\
\hline Basic infrastructures & .333 & .159 & .211 & .213 & .353 \\
\hline \multicolumn{6}{|c|}{ Middle East } \\
\hline & $\begin{array}{l}\text { Total weight of energy } \\
\text { investments }\end{array}$ & Right of investigation & Right of extraction & Property right of oil field & Oil/gas supply \\
\hline Basic infrastructures & .304 & -.091 & .395 & .102 & $.718^{*}$ \\
\hline \multicolumn{6}{|c|}{ Central Asia } \\
\hline & $\begin{array}{l}\text { Total weight of energy } \\
\text { investments }\end{array}$ & Right of investigation & Right of extraction & Property right of oil field & Oil/gas supply \\
\hline Basic infrastructures & .643 & .298 & .066 & $.941^{*}$ & -.327 \\
\hline \multicolumn{6}{|c|}{ Africa } \\
\hline & $\begin{array}{l}\text { Total weight of energy } \\
\text { investments }\end{array}$ & Right of investigation & Right of extraction & Property right of oil field & Oil/gas supply \\
\hline Basic infrastructures & -.013 & -.136 & -.182 & .032 & -.106 \\
\hline
\end{tabular}

Source of Data: Made by author according to data listed in Tables 2-7.

Table 15.

Rights gained by Chinese energy enterprises through merger and acquisition within overall rights gained.

\begin{tabular}{|c|c|c|c|c|c|c|c|c|}
\hline & \multicolumn{3}{|c|}{ Right of oil field } & \multirow{2}{*}{$\begin{array}{l}\text { Oil/gas } \\
\text { supply }\end{array}$} & \multicolumn{3}{|c|}{ Basic infrastructure } & \multirow[b]{2}{*}{ Total } \\
\hline & $\begin{array}{c}\text { Right of } \\
\text { investigation }\end{array}$ & $\begin{array}{l}\text { Right of } \\
\text { extraction }\end{array}$ & $\begin{array}{l}\text { Property right } \\
\text { of oil field }\end{array}$ & & $\begin{array}{l}\text { Refinement } \\
\text { of crude oil }\end{array}$ & $\begin{array}{l}\text { Store of } \\
\text { crude oil }\end{array}$ & $\begin{array}{l}\text { Transport of } \\
\text { crude oil }\end{array}$ & \\
\hline Amount & 57 & 35 & 92 & 0 & 1 & 0 & 0 & 155 \\
\hline Percentage (\%) & 36.77 & 28.23 & 76.03 & .00 & 4.55 & .00 & .00 & 39.36 \\
\hline
\end{tabular}

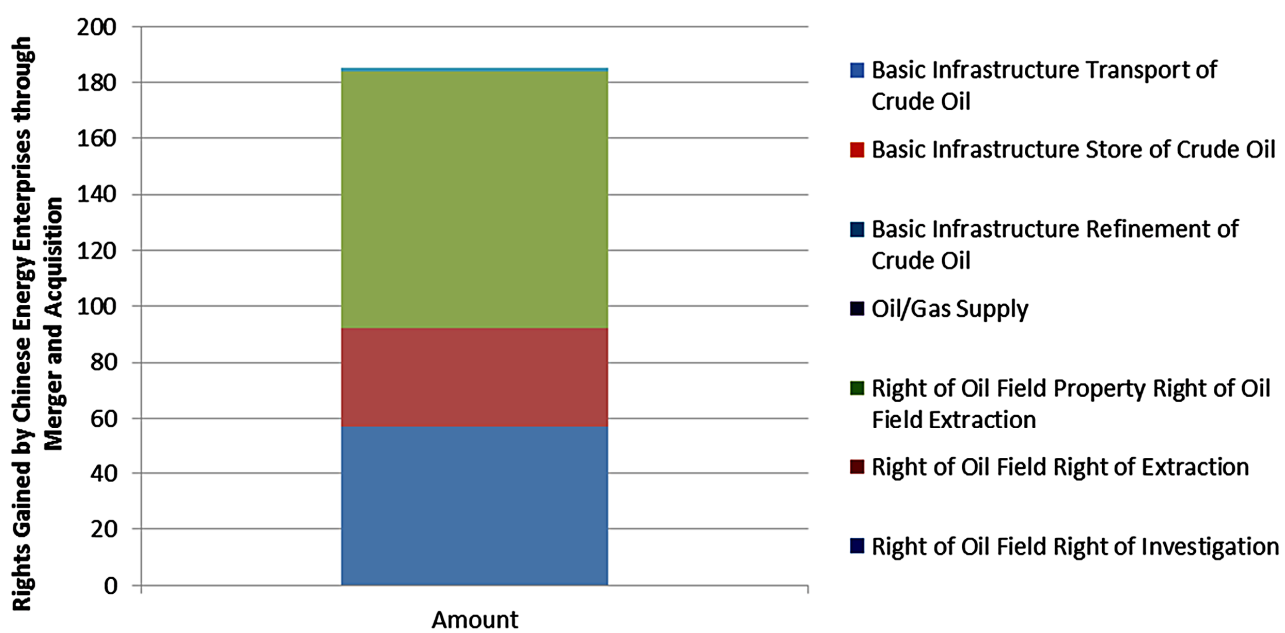

Figure 7.

Rights gained by Chinese energy enterprises, through mergers and acquisitions, displaying overall rights gained.

In mergers and acquisitions, enterprises had greater independence and profit-to-loss ratios than through negotiations with the host country led by the government. From 2003 to 2010, $76.03 \%$ of the total rights of oil fields acquired by Chinese energy corporations were gained through mergers and acquisitions. Overseas investment through trans-national mergers and acquisitions and through merging Western energy corporations compensated for deficient extraction technologies. Such investments helped energy corporations obtain new technology and also to avoid condition exchange with host countries. In this way, resource allocation and global deployment became more efficient and effective. 
Table 16 presents the change in overseas investment quantity by Chinese energy corporations over the years, and the rights acquired through mergers and acquisitions. Except for the large decline of overseas mergers and acquisitions around 2007, mergers and acquisitions were seen as the main investment pattern for overseas investment by Chinese energy corporations. This trend became increasingly evident after 2008 .

From 2003 to 2006, the percentage of mergers and acquisitions was 27.91; however, from 2008 to 2010, this increased to $57.36 \%$. This change signalled the changing relationship between the Chinese government and the enterprises in China's energy diplomacy. Governmental influence in enterprises is refocusing on broader objectives that are set by the government while enterprises have complete control over investment decisions.

Literature studying the relationships between China's energy SOEs and government concede that the Chinese government does not dominate the SOEs; on the contrary, since SOEs have maximized annual profits, the executives have greater influence over the government than before (Downs, 2009; Liou, 2009).

According to such literature, the observations and inferences mentioned above do not necessarily mean that Chinese energy corporations lack any government control. They imply that once energy security needs were met, investment costs and profits should then be considered in economic activities. China's investment in Central Asia, from 2006 to 2010, establishing channels of "west gas-transport east" was the main mission for Chinese energy enterprises. Furthermore, the agree- ment between the CNPC and Turkmenistan, signed in 2007, ensured that one billion cubic metres of natural gas will annually pass through the Central Asia gas pipeline built by the CNPC, until 2038. This amount increased to 1.3 billion cubic metres annually in 2008. Upon establishing the annual amount of piped natural gas, the CNPC purchased Mangistau Munai Gas and acquired 15 rights of extraction and investigation on oil fields in Kazakhstan.

In summary, mergers and acquisitions of trans-national enterprises became the main approach for overseas investment by Chinese energy corporations. In contrast to the initial stages of outreach which necessitated government influence, Chinese energy corporations are growing stronger internationally, thereby transforming the relationship between Chinese energy corporations and the government. While the government influences enterprises' investment strategy through energy security policies, enterprises now adjust investment strategies while balancing the government's will and investment costs.

\section{Conclusion: Implications of Chinese Energy Diplomacy Policy on Neo-Mercantilism}

According to the empirical data provided, it is necessary for the Chinese government to guide and aid Chinese energy corporations in fulfilling the policy of outreach. With the precondition of China's political system and its energy corporations' lagged development in the international market, mercantilism inevitably became the main approach of Chinese energy diplomacy.

Table 16.

Rights and benefits gained by Chinese energy enterprises through mergers and acquisitions between 2003 and 2010.

\begin{tabular}{|c|c|c|c|c|c|c|c|c|c|}
\hline Year & 2003 & 2004 & 2005 & 2006 & 2007 & 2008 & 2009 & 2010 & Total \\
\hline Overall investment cases & 54 & 61 & 97 & 46 & 15 & 28 & 108 & 61 & 470 \\
\hline Azerbaijan & 1 & 0 & 0 & 0 & 0 & 0 & 0 & 0 & 1 \\
\hline Tunisia & 24 & 4 & 0 & 0 & 0 & 0 & 0 & 0 & 28 \\
\hline Kazakhstan & 3 & 8 & 20 & 0 & 0 & 2 & 32 & 7 & 42 \\
\hline Iran & 0 & 1 & 0 & 0 & 0 & 0 & 0 & 0 & 1 \\
\hline Sudan & 0 & 2 & 0 & 0 & 0 & 0 & 0 & 0 & 2 \\
\hline Gabon & 0 & 0 & 1 & 0 & 0 & 0 & 10 & 0 & 11 \\
\hline Mauritania & 0 & 0 & 2 & 0 & 0 & 0 & 0 & 0 & 2 \\
\hline Syria & 0 & 0 & 1 & 0 & 0 & 8 & 0 & 40 & 49 \\
\hline Nigeria & 0 & 0 & 0 & 2 & 0 & 0 & 7 & 0 & 9 \\
\hline UAE & 0 & 0 & 0 & 1 & 0 & 0 & 0 & 0 & 1 \\
\hline Iraq & 0 & 0 & 0 & 0 & 0 & 0 & 4 & 0 & 4 \\
\hline Niger & 0 & 1 & 0 & 0 & 0 & 0 & 0 & 0 & 1 \\
\hline Angola & 0 & 0 & 0 & 0 & 0 & 0 & 1 & 0 & 1 \\
\hline Chad & 1 & 0 & 0 & 0 & 0 & 0 & 0 & 0 & 1 \\
\hline Cameroon & 0 & 0 & 0 & 0 & 0 & 0 & 2 & 0 & 2 \\
\hline Total & 29 & 16 & 24 & 3 & 0 & 10 & 26 & 47 & 155 \\
\hline Rights/benefits gained in \% & 53.70 & 26.23 & 24.74 & 6.52 & .00 & 35.71 & 51.85 & 77.05 & 39.36 \\
\hline
\end{tabular}


However, the government and enterprises view overseas energy investments differently. The government places greater concern on whether such investment decisions fulfil energy security policies, whereas, enterprises focus on profitability. With Chinese energy corporations' increasing international development and the recovery of Western enterprises following the global financial crisis, the investment strategies of Chinese energy corporations are transforming. Though these strategies for overseas investment are still based on governmental energy security policies, Chinese energy corporations are capable of pioneering numerous key factors and hence achieving efficiency. One key adjustment is to gradually decrease negotiations between the host and Chinese government. Instead, Chinese energy corporations are expanding overseas investment through mergers and acquisitions.

In implementing such energy security policies, upon meeting partial demands outlined in the policy, Chinese energy corporations adopt more efficient ways to expand overseas investments. Based on the government's energy security policy, Chinese energy corporations seek more efficient mergers and acquisitions thereby transforming energy diplomacy from state-based to economy-based. Moreover, the implementation of such actions moves initiatives from the government to enterprises. Enterprises no longer need to depend on negotiations between governments; they may negotiate directly with the host government, state-owned enterprise, or Western enterprises. These changes allow Chinese energy diplomacy to attain higher efficiency and more importantly, enrich the connotations embedded within mercantilism.

Mercantilism emphasized the role of the nation, while liberalism believes that nations play a minimal role. Hence, the case with Chinese energy corporations seems to challenge both mercantilism and liberalism. According to the empirical research on Chinese energy diplomacy and the overseas investment of Chinese energy corporations, it is possible for mercantilism and liberalism to pre-conditionally co-exist. The precondition holds that enterprises require a degree of independence in strategy mapping, while fulfilling governmental policy, and that investment decisions should be based on economic evaluations.

However, despite considering that prices in the energy market are not determined by the supply-demand curve, the energy market is monopolized by trans-national corporations and international organizations. The phenomenon may be the result of government considerations, since direct mergers and acquisitions of trans-national corporations can gain rights associated with oil fields, and also enhance the nation's status internationally. Furthermore, with this enhanced status, the government can take greater control in agenda setting. In order to test this hypothesis, a more complete and holistic picture of the structural change in international energy markets is needed, along with more interviews analyzing the will of the Chinese government. These issues may be the focus of future studies and investigations.

\section{REFERENCES}

African Development Bank \& the African Union (2009). Oil and gas in Africa (pp. 80-81). New York: Oxford University Press.

Angevine, G. \& Cameron, B. (2007). Fraser institute global petroleum survey (pp. 9-11). Toronto: Fraser Institute Press.

Blair, D. (2007). Why China is trying to colonize Africa? The Telegraph, 31 August.

Bohning, W. R. (1979). International migration and the international economic order. Journal of International Affairs, 33, p. 188.

Brander, J. (1995a). Strategic trade policy, NBER working papers, No. 5020 (pp. 65-66). Cambridge: National Bureau of Economic Research.

Brander, J. A. (1995b). Strategic trade policy. In G. Grossman, \& K. Rogoff (Eds.), Handbook of International Economics, Vol. III (p. 1397). New York: North Holland Press.

Buzan, B., \& Little, R. (2000). International systems in world history: Remaking the study of international relations (pp. 293-294). New York: Oxford University Press.

Byman, D., Chubin, S., Ehteshami, A., \& Green, J. (2001) Iran's security in the post-revolutionary era (pp. 62-64). Santa Monica, CA: Rand Corporation Press.

Cordesman, A. H., \& Al-Rodhan, K. R. (2006). The changing dynamic of energy in Middle East (p. 168). Washington DC: Center for International Strategies and Studies Press.

Dougherty, J. E., \& Pfaltzgraff, R. L. (2002). Contending theories of international relations: A comprehensive survey (p. 428). New York: Longman press.

Downs, E. S. (2004). The Chinese energy security debate. The China Quarterly, 177, 37. doi:10.1017/S0305741004000037

Downs, E. S. (2009). Business interest groups in Chinese politics: The case of the oil companies. In C. Li (Ed.), China's changing political landscape: Prospects for democracy (pp. 121-141). Washington DC: The Brookings Institution Press.

Fravel, M. T. (2005). Regime insecurity and international coop eration: Explaining China's compromises in territorial disputes. International Security, 30, 80.doi:10.1162/016228805775124534

Garver, J. (2006). China and Iran: Ancient partners in a post-imperial world (pp. 95-128). Seattle, WA: University of Washington Press.

Gill, B. (2007). Rising star: China's new security diplomacy (pp. 37-52, 165). Washington DC: Brookings Institution Press.

Gilpin, R. (1987). The political economy of international relations (pp. 32-37, 180). Princeton, NJ: Princeton University Press.

Goldstein, J. S. (2003). International relations (p. 306). New York: Longman.

Held, D., Mcgrew, A., Goldblatt, D., \& Perraton, J. (1999) Global transformations: Politics, economic and culture (p. 183). London: Blackwell Publisher Ltd.

Jiang, J., \& Sinton, J. (2011) Overseas investment by Chinese national oil companies: Assessing the drivers and impacts (pp. 17-20). Paris: International Energy Agency.

Krugman, P. R. (1986). Introduction: New thinking about trade policy. In P. R. Krugman (Ed.), Strategic trade policy and the new international economics (p. 12). Massachusetts: The Massachusetts Institute of Technology Press.

Krugman, P. R. (1994). Peddling prosperity: Economic sense and nonsense in the age of diminished expectations (p. 247). New York: W.W. Norton.

Lairson, T. D., \& Skidmore, D. (2002). International political economy: The struggle for power and wealth (p. 12). Belmont, CA: Wadsworth Publishing Press.

Latourrette, T., Bernstein, M., Hanson, M., Pernin, C., Knopman, D., \& Overton, A. (2003) Assessing natural gas and oil resources: An example of a new approach in the Greater Green River Basin (pp. 23-26). Santa Monica, CA: Rand Cooperation Press.

Li, D. (2003). The Strategy of energy security: Going out forever. Outlook Weekly, 34, 38-40.

Liou, C.-S. (2009). Bureaucratic Politics and Overseas Investment by state-owned oil companies: Illusory champions. Asian Survey, 49, 4, 670-690. doi:10.1525/as.2009.49.4.670

Markusen, J. R., Melvin, J. R., Kaempfer, W. M., \& Maskus, K. E. (1995). International trade: Theory and evidence (p. 374). New York: McGraw-Hill.

Mcdermott, J. (1999). Mercantilism and modern growth. Journal of Economic Growth, 4, 56. doi:10.1023/A:1009878625417

Nincic, D. J. (2009) Troubled waters: Energy security as maritime security. In G. Luft, \& A. Korin (Eds.), Energy security challenges for the 21st century: A reference handbook (p. 98). Santa Barbara, CA: Greenwood Publishing Group Press.

Oresman, M. (2007) Repaving the silk road: China's emergence in 
Central Asia. In J. Eisenman, et al. (Eds.), China and the developing world: Beijing's strategy for the twenty-first century (pp. 60-83). New York: M.E. Sharpe Press.

Polgreen, L., \& French, H. W. (2007). New power in Africa: China's trade in Africa carries a price tag. New York Times, 21 August.

Reimer, J. J., \& Stiegert, K. W. (2006). Evidence on imperfect competition and strategic trade theory: Evidence for international food and agricultural markets, Journal of Agricultural \& Food Industrial Organization, 4, 1136-1137.

Schmiegelow, H., \& Schmiegelow, M. (1975). The new mercantilism in international relations: The case of France's external monetary policy. International Organizations, 29, 369.

doi:10.1017/S002081830000494X

Snow, P. (1995). China and Africa: Consensus and camouflage. In T. W. Robinson, \& D. Shambaugh (Eds.), Chinese foreign policy: Theory and practice (pp. 285-287). Oxford: Clarendon Press.

Sutter, R. G. (2008). Chinese foreign relations: Power and policy since the Cold War (p. 309). Maryland: Rowman \& Littlefield, Inc.

Taylor, I. (2004). The "all-weather friend"? Sino-African interaction in the twenty-first century. In I. Taylor, \& P. Williams (Eds.), Africa in international politics: External involvement on the continent (pp.
84-87). New York: Routledge Press.

Thurow, L. (1992). Head to head: The coming economic battle among Japan, Europe, and America (pp. 245-58). New York: William Morrow.

Tull, D. M. (2006). China's engagement in Africa: Scope, significance, and consequences. The Journal of Modern African Studies, 44, 460462. doi:10.1017/S0022278X06001856

Wang, J. (2004). China petroleum security and geography politics. Resources and Industries, 6, 3-7.

Wang, J.-H. (2003). Globalization and latecomers: Implications of the East Asian development model and its transition. Taiwanese Journal of Sociology, 31, 1-45.

Xinhua (2006). The 11th five-year plan. Xinhua, 28 February. http://service2.xinhuanet.com/cgi-bin/redirect.cgi?refresh=http://engl ish.gov.cn/special/2006_11th.htm

$\mathrm{Xu}, \mathrm{X} .(1998)$. The geopolitics of oil and gas in the new century: China's opportunities and challenges. Beijing: Social Sciences Academic Press (China).

Zekun, C. (2004). The problem of petroleum security under new global geovisions on petroleum and the strategic thinking about China's petroleum security. International Studies, 2, 67-69. 